\title{
GEOLOGICAL ASSOCIATION OF CANADA \\ NEWFOUNDLAND SECTION \\ ANNUAL MEETING
}

\section{SEABED PROCESSES AND RESOURCES}

\author{
MARCH 17-18, 1994 \\ MEMORIAL UNIVERSITY OF NEWFOUNDLAND
}

The annual meeting of the Newfoundland Section of the Geological Association of Canada was devoted to research in seabed processes and seabed resources. It focused on coastal and continental shelf areas of Newfoundland and eastern Canada. Diverse topics related to the various aspects of seabed geology were presented, including sedimentary basin analysis, modern sedimentary processes, Quaternary marine sedimentation, and reality of marine mining. The eclectic combination of lectures also covered geological significance of iceberg scouring of the seafloor, as well as environmentally sensitive issues of harvesting of shellfish and tracing provenance of seawater pollution in St. John's Harbour.

The following pages include abstracts, in alphabetical sequence, of the papers presented at the conference.

The conference was jointly organised by the Newfoundland Section of the Geological Association of Canada and the Department of Earth Sciences, Memorial University of Newfoundland.

Organising Committee, Geological Association of Canada - Newfoundland Section

Tomasz Dec and Donald James

Geological Survey Branch

Department of Mines and Energy
Kelly Steinhauer and Derek Wilton Department of Earth Sciences

Memorial University of Newfoundland 


\title{
Exploring the wreck of the Titanic: seabed processes at $\mathbf{3 8 0 0}$ metres in the North Atlantic
}

\author{
S.M. Blasco \\ Atlantic Geoscience Centre, Geological Survey of Canada, Bedford Institute of Oceanography, \\ Dartmouth, Nova Scotia B2Y 4A2, Canada
}

The wreck of the passenger liner Titanic lies in 3800 $m$ of water on the continental rise adjacent to the southeastern tip of the Grand Banks of Newfoundland. Sunk on her maiden voyage 82 years ago, the Titanic represents a unique time gauge by which to assess environmental processes active in the deep waters of the North Atlantic. Two Russian Academy of Sciences ' 3 person' MIR submersibles and the research vessel Akademik Keldysh were contracted by IMAX Corporation in June 1991 to film a large format documentary and to conduct a scientific investigation of the wreck site. Seventeen submersible dives averaging 14 hours in duration were completed. State-of-the-art broadcast quality video, 3-D video, IMAX $70 \mathrm{~mm}$ film, and wide angle still photographic imagery of the wreck site were acquired. Bottom sediment core samples and metal fragments were recovered by remote manipulators on the MIR 2 submersible. The wreck lies in 2 pieces on the floor of Titanic Canyon. The intact bow and badly damaged stern sections are separated by $600 \mathrm{~m}$. Initial findings suggest the seabed at $3800 \mathrm{~m}$ depth is more environmentally active and dynamic than anticipated. Bottom currents up to 1 knot were observed. Patches of active, wave generated symmetric sand ripples are located in close proximity to the wreck and debris field. In response to current action, a thin veneer of recent sediment is being pref- erentially deposited in the leeward areas of the decks. Seabed sediments consist of surficial recent soft muds and sands, 10 to $15 \mathrm{~cm}$ thick, unconformably overlying dense friable clays of infinite radiocarbon age. At the unconformity, approximately $20 \mathrm{~m}$ of the dense clays have been eroded since deposition. More resistant beds subcrop on the canyon floor as $3 \mathrm{~m}$ high ridges or scarps covered with the recent soft muds. 'Icicles' of rust or rusticles hanging from the wreck are frequently bent or curved by prevailing currents. Corrosion appears to be controlled more by biological rather than chemical processes. Fauna inhabiting the wreck site are more abundant, with twice the diversity anticipated by biologists. Twenty-four species of invertebrates (crabs, shrimps, anemones, sponges, starfish, corals, etc.) and four species of fish, including large Grenadier or rat-tail fish, were observed. Metallurgical analysis of a recovered hull plate fragment indicates that the ship's plating was brittle, suggesting that the iceberg damage was more extensive than previously thought. The scientific program was a joint project with the Russian Academy of Sciences, CANMET, Petro-Canada, the National Geographic Society, and the Geological Survey of Canada, and was funded by IMAX Corporation and the Federal Program on Energy Research and Development (PERD).

\section{Environmental impact of shallow water small-scale marine placer mining}

\author{
I.B. Clark 1, L. Davis 2 and W.J. Scott ${ }^{2}$ \\ IDepartment of Earth Sciences, Memorial University of Newfoundland, St. John's, Newfoundland A1B 3X5, Canada \\ ${ }^{2}$ Centre for Cold Ocean Resources Engineering (C-CORE), Memorial University of Newfoundland, \\ St. John's, Newfoundland AIB 3X5, Canada
}

A shallow water, small-scale marine placer gold mining test study is to take place this summer at Pine Cove, Baie Verte, Newfoundland. Three mining methods will be applied including a SCUBA diver assisted hydraulic dredge, a remotely controlled crawler-mounted hydraulic dredge, and a conventional clamshell dredge. A multi-year monitoring program will determine the physical, chemical and biological environmental impacts associated with the mining operations.

\section{The mysterious disappearance of the Great Auk and Northern Cod: is the northwest Atlantic ecosystem in crisis?}

\author{
R.G. Coombs \\ Department of Fisheries, Government of Newfoundland and Labrador, P.O. Box 8700, \\ St. John's, Newfoundland A1B 4J6, Canada
}

Contemporary scientific debate and investigation on the catastrophic decline of the Northern Cod stock is focusing on the purported instantaneous disappearance of approximately 500,000 metric tonnes of biomass on or about February of 1992. This science is directed primarily at the investigation of environmental anomalies coincident with the decline. This presentation offers a cursory examination of some of the suggested contributors to the current resource crisis and proposes an alternate, more salient culprit to the problem. A review of macroscopic indicators from a biological and historical analysis of the fishery provides a simple explanation of the events which is unpalatable to existing fisheries epistemology. Historical catches of northern cod, spawning stock biomass and retrospective $F_{0.1}$ 's can be used to exhibit a decline of the Northern Cod Stock since 1960a decline from which the stock has never been permitted to recover. 


\title{
An overview of the surficial and shallow bedrock geology of the Grand Banks of Newfoundland
}

\author{
G.B.J. Fader and R.O. Miller \\ Geological Survey of Canada, Bedford Institute of Oceanography, P.O. Box 1006, \\ Dartmouth, Nova Scotia B2Y 4A2, Canada
}

The Geological Survey of Canada has been involved in the mapping and study of the Quaternary and shallow bedrock geology of the Grand Banks of Newfoundland for the past 20 years. This has resulted in the production of a suite of published maps and reports and a regional understanding of the geological history.

Quaternary sediments are very thin on most of the offshore bank areas, overlying a monotonous sequence of shallow, seaward dipping, Tertiary strata. The present seabed sediments were derived through reworking of previously deposited glacial materials during a post glacial sea level fall and subsequent Holocene marine transgression. Sediment transport is widespread in depths shallower than $100 \mathrm{~m}$, and the predominant bedforms consist of sand ridges, sand ribbons, sand waves, megaripples and ripples in gravel. Bedform orientations suggest sediment transport to the southwest. Sand ridges are the largest bedforms and are oriented more or less north-south. Their origin is not clearly understood. Some may in part be relict with cores of late Wisconsinan morainal coarse sediment, while others may be modern features formed in response to infragravity waves.

The timing and extent of glacial ice across the Grand Banks has been difficult to determine, as most of the glacial sediments are buried beneath thick sand and gravel deposits, resulting in problems in sampling. Much of the glacial section on the shallow bank areas has also been eroded during the Holocene marine transgression. However, large interbank channels, and a few areas beneath the shelf edge, contain sequences of multiple tills in the form of till tongues, which interbed with thick glaciomarine sediments. These mark positions of former grounded ice margins and can be easily dated. Their distribution indicates that late Wisconsinan ice was extensive and likely covered the entire continental shelf area off Newfoundland.
An area in Halibut Channel containing multiple tills has been sampled with a series of boreholes. Geotechnical, biostratigraphic, chronostratigraphic and seismostratigraphic analyses suggest that both early and late Wisconsinan ice was extensive across the shelf south of Newfoundland. Ice domes may have formed during late Wisconsinan ice retreat on the outer banks and were isolated from Newfoundland centered ice.

Recent studies on northern Grand Bank and the southern part of the Northeast Newfoundland Shelf have revealed a complex Quaternary stratigraphy with varying styles of glacial deposition: (1) a large ice stream with a floating front in Trinity Trough, and (2) a retreating ice sheet margin that changed from a floating front to a tidewater front in shallower water. Till deltas, together with terraced and ribbed moraines, indicate a change in ice marginal conditions. Buried and open meltwater channels are interpreted as subglacial tunnel valleys. Some occur in a radiating pattern with the deposition of distal, $90 \mathrm{~m}$ thick, coarse morainal banks at the seaward end of the valleys, interpreted to have been deposited in a tidewater frontal environment.

A wide variety of other seabed and subsurface features occur across the Grand Banks of Newfoundland and include iceberg furrows and pits, megaflutes, pockmarks, gas-charged sediments, active gas vents, boulder fields and unusual "W"shaped bedforms. Regional surveys have identified large quantities of offshore sand and gravel that could be suitable for aggregate applications. Geological surveys have also identified the presence of dense benthic communities of sea cucumbers and shellfish and have contributed to studies, presently under way, in assessing the effects of bottom fishing gear on seabed habitat.

\section{Marine mining - this is reality}

\author{
R.H.T. Garnett \\ Valrik Enterprises Incorporated, 276 Beechfield Road, Oakville, Ontario L6J 5H7, Canada
}

Marine mining was first attempted on a significant scale nearly a century ago. The target was gold: the seaward extension of the famous beaches of Nome, Alaska. Shortly thereafter the offshore dredging of tin ore was commenced in South East Asia and for decades constituted a major industry. Activities continue to this day in Indonesian waters, despite low tin metal prices.

The 1950s witnessed a rapid growth in the offshore aggregate dredging industry in Western Europe. Most of the sand and gravel used there is now derived from the sea. At the other depth extreme enormous engineering difficulties were overcome in the 1970 s to recover manganese nodules from the Pacific Ocean.
The pace of development has increased rapidly in the last few years. The equipment necessary for mining a variety of marine deposits is now available from other industries.

The birthplace of new marine mining techniques has become southern Africa where offshore diamond mining, with the active encouragement of governments, now rates as a major mining industry. The rapidly increasing activity extends from small, part-time enterprises to large scale operations by some of the world's largest major companies.

Marine mining is now a proven, profitable industry for many countries. 


\title{
Acoustic measurements of sediment transport processes in the nearshore zone
}

\author{
A.E. Hay \\ Department of Physics, Memorial University of Newfoundland, St. John's, Newfoundland AIB 3X7, Canada
}

Sediment transport in the oceanic bottom boundary layer involves three-fold coupling among: (1) the motion of sediment grains, (2) the response of the bed, and (3) the fluid forcing. The appeal of acoustic remote sensing methods is that in principle all three components of the problem can be addressed with minimal disturbance to the system. This paper summarizes some of the progress that has been made to date toward improving our ability to make real-time observations of sediment transport processes in the nearshore zone throughout the course of storm events. Results are presented for several different types of measurement: (1) range-gated multifrequency backscatter to obtain profiles of suspended sediment concentration and size, (2) bedform imaging, and (3) suspended sediment fluctuations under waves. The results both demonstrate the promise of the approach, and raise a number of fundamental questions about our understanding of nearshore processes.

\section{The behaviour of quaternary debris flows on the northeast Newfoundland slope}

\author{
A.M. Mahgoub \\ Department of Earth Sciences, Memorial University of Newfoundland, St. John's, Newfoundland AIB 3X5, Canada
}

High resolution $(3.5 \mathrm{kHz})$ reflection profiles indicate that a significant portion of the northeast Newfoundland slope (between longitude $46^{\circ}$ to $52^{\circ} \mathrm{W}$ and latitude $48^{\circ}$ to $51^{\circ} \mathrm{N}$ ) consists of Quaternary debris flow deposits (debrites) of glacigenic origin. Generally these debrites appear as well defined, seismically transparent lenses aligned down the slope up to a distance of $200 \mathrm{~km}$ from the shelf edge. These lenses have central thicknesses ranging from few meters near the seafloor to tens of meters in deeper horizons (visible up to $100 \mathrm{~m}$ depth). They are 0.5 to $75 \mathrm{~km}$ long and 0.5 to $25 \mathrm{~km}$ wide. They travelled on a very gentle slope $\left(1.5^{\circ}\right.$ to about $0.1^{\circ}$ ) without significantly eroding the underlying sediments.

Cores from debrite lenses reveal structureless, poorly sorted pebbly mud with numerous lithic fragments as well as soft mud clasts. The fine fraction consists of 10 to $39 \%$ sand, 17 to $23 \%$ silt and 43 to $67 \%$ clay. Clay samples contain about $45 \%$ illite and $35 \%$ chlorite.

Laboratory measurements of pore fluid pressure were made on a sediment core from a shallow debrite. The sediment was reconstituted to form slurries of different water content. These slurries develop high values of excess pore fluid pressure (approximately 0.7 to 2.5 times hydrostatic, depending on depth and sediment concentration). These high values were maintained for several hours before slowly dissipating. This is mainly due to the poor sorting and the high amount of fines. High pore pressures effectively mobilised these flows by reducing the total normal stress and consequently the shear strength to about $<5 \%$ of the original value.

\section{Late Wisconsinan subaqueous outwash deposits in northeast Newfoundland}

\author{
M. Munro and N. Catto \\ Department of Geography, Memorial University of Newfoundland, St. John's, Newfoundland AlB 3X9, Canada
}

Relative sea levels at the end of the last glaciation were raised to at least $57 \mathrm{~m}$ asl in northeast Newfoundland. Consequently, a belt of land at least $5 \mathrm{~km}$ wide was submerged by ocean water. Littoral beach gravels account for the majority of sediments related to higher sea levels. Near Musgrave Harbour, however, emerged ice marginal subaqueous deposits are associated with sea levels higher than $46 \mathrm{~m}$ asl. These formed in waters up to $32 \mathrm{~m}$ deep.

As glacial ice retreated in the area, increased meltwater production resulted in several gravel fans being deposited rapidly proglacially. Rapid sand and silt deposition took place between the fans forming proximal rhythmites which grade laterally into rippled deposits. More gravel fans were deposited on the top of these. The fans join to form a ridge approximately $15 \mathrm{~km}$ long by up to $4 \mathrm{~km}$ wide.
Loading of the finer deposits by the gravels resulted in extensive deformation and dewatering, with resultant sedimentary features including diapers, flame structures, dish and pillar structures, ball and pillow structures, and recumbent folds. Interbedded with the gravels and silts are many sediment gravity flow deposits. These are mainly debris flow, fluidized grain flow, and turbidity current deposits. Proglacial deposition resulted in the formation of a moraine ridge almost $15 \mathrm{~km}$ long. This, however, does not represent a lengthy stillstand of ice.

Further melting of the ice resulted in collapse and faulting of proximal sediments and further deformation due to dewatering. As sea levels dropped, the upper surfaces of many of these deposits were reworked by marine action to form beach terraces. 


\title{
Fisheries for shellfish in Newfoundland
}

K.S. Naidu

Science Branch, Department of Fisheries and Oceans, P.O. Box 5667, St. John's, Newfoundland A1C 5X1, Canada

In Newfoundland, fisheries for invertebrates are directed primarily at shrimp, crab, lobster, scallops and clams. The relative contribution of shellfish, both in terms of nominal catch and landed value, compared to fin fish has been increasing steadily over the last decade. In 1992, for example, over half the landed value of fish products in Newfoundland came from invertebrates. In part, this is due to dra- matic declines in the abundance of fin fish, especially cod. Equally important is the relatively high unit value of invertebrates compared to most fin fish species.

This contribution summarizes the fishery in Newfoundland based on invertebrates. Mass harvesting techniques are discussed in the context of concerns for environment perturbation and habitat modification.

\section{Sources and pathways of polycyclic aromatic hydrocarbons in St. John's most famous body of water}

\author{
V. O'Malleyl, J. Hellou' ${ }^{2}$, L. Winsor' ${ }^{1}$ and T. Abrajanol \\ 1 Department of Earth Sciences, Memorial University of Newfoundland, \\ St. John's, Newfoundland, Canada AIB 3X5, Canada \\ 2Science Branch, Department of Fisheries and Oceans, P.O. Box 5667, St. John's, Newfoundland AIC 5XI, Canada
}

Polycyclic aromatic hydrocarbons (PAH) of natural and anthropogenic origin are among the largest class of known and suspected carcinogens and mutagens in the environment. Because of the hydrophobic and lipophilic nature of PAH, sediments and particulates are excellent "repositories" for these compounds in aquatic systems. Sediments also therefore offer the best means of evaluating the relative contributions of PAH sources in these systems as a function of space and time. Our approach in the evaluation of PAH sources in environmental samples is to utilize, in addition to molecular distributions, the variations in the ratios of $13 \mathrm{C} / 12 \mathrm{C}$ in individual PAH.

Molecular analyses and carbon isotopic characterization of individual PAH were performed on sediments collected from several stations in the St. John's Harbour. The overall abundances of PAH observed in the Harbour make it one of the most heavily contaminated estuaries in North America. Comparison of the molecular and isotopic compositions of the sedimentary PAH to similar signatures of various potential primary and secondary PAH sources in the Greater St. John's area enabled quantitative assessment of the relative contributions of petroleum-related sources (e.g., crankcase oil, fuel oils) and combustion-related sources (e.g., woodburning and automobile exhaust) to the PAH inventory of the Harbour. Although significant input of petroleum-related PAH may be expected from shipping and crankcase oil disposal, our estimate of this contribution rarely amounted to $50 \%$ of the total PAH. For most of the Harbour sediments, combustion sources (car emission and woodburning) are the dominant contributors, possibly as a result of extensive snow dumping and discharge of untreated effluent from sewers.

\section{The November 18, 1929 'Tidal Wave': Canada's most tragic earthquake}

\author{
A. Ruffman \\ Geomarine Associates Limited, 5112 Prince Street, P.O. Box 41, Station 'M', Halifax, Nova Scotia B3J 2L4, Canada
}

The 'Grand Banks' Earthquake struck at 17:02 NST. It was centred $20 \mathrm{~km}$ beneath the Laurentian Continental Slope, $350 \mathrm{~km}$ south of Newfoundland. The lack of nearby seismometers at the time meant that the epicentre was difficult to determine accurately. A recent reassessment of the world's seismograms from this event by the Geological Survey of Canada has shown the rupture to have been a right lateral strike-slip, northeast-southwest trending, fault with the rupture progressing to the northeast. The event had a surface wave magnitude of 7.2 (MS 7.2; $\mathrm{mB} 7.1 ; \mathrm{MW} 7.1$ ), and it was felt as far afield as New York City and Montreal; there is even a serendipitous felt-report in Bermuda. Onshore the damage from the earthquake's shaking was restricted to some slumping and minor building damage in Cape Breton Island; Newfoundland, despite its proximity to the epicentre, experienced no damage other than broken crockery shaken off shelves because most structures were of wood-frame construction built on solid substrates. Offshore on the ocean floor part of the Laurentian Slope was shaken loose and began an underwater landslide that went on for hours and flowed $1500 \mathrm{~km}$ out onto the floor of the Sohm Abyssal Plain. It was 19 years before scientists recognized the landslide and its great importance as a dominant ocean process. The 1929 'turbidity current' cut twelve trans-Atlantic telegraph cables and repairs stretched well into 1930.

The submarine slump spawned a 'tsunami' that travelled at about $500 \mathrm{~km} / \mathrm{hr}$ south and eastwards; it was seen on tide gauges as far afield as Charleston, South Carolina, in the Azores and on the coast of Portugal. The tsunami travelled at about $140 \mathrm{~km} / \mathrm{hr}$ over the continental shelf north and westwards. The full force of the tsunami struck the south coast of Newfoundland at about 1930 to 2000 NST after 
dark. Luckily most persons were still awake and up and about to facilitate their escape. Contrary to popular scientific belief, the tsunami did not arrive during a storm; it was a calm moonlit night. Three main pulses swept in; at the heads of the long narrow bays on the Burin Peninsula the tsunami arrived as foaming, breaking waves near the top of a rising 'spring' tide. Over a period of five to ten minutes sea levels rose 3 to $7 \mathrm{~m}$ above normal, lifting houses off their shores, tearing loose anchored vessels and destroying virtually all shore property, wharves and fish stores. Twenty-nine persons died; twenty-six persons died that night, one infant died two days later and another child of injuries 3.3 years after the event, with another death that night in Nova Scotia. The tsunami refracted counterclockwise around the Avalon Peninsula and affected northeast Newfoundland in the early hours of November 19, five to six hours after it devastated the south-facing harbours of the Burin Peninsula. A major storm tide accompanied a large winter storm in Newfoundland on November 19, just after daybreak. This high lunar/ storm tide is often confused by people who remember it as having been the effects of the 'tidal wave' that caused 'The South Coast Disaster'. The visible effects of the tsunami were seen elsewhere outside the Burin Peninsula on Newfoundland's south coast, in Saint Pierre et Miquelon, on Cape Breton Island where minor damage was done, and on along the Atlantic Coast to Halifax and Lunenburg; there was minor damage in Bermuda with the early evening breaking of anchor chains. It is popularly believed by many Newfoundlanders that the early 1930 s collapse of the fisheries and the loss of the eel grass was a direct result of the 'tidal wave'; this observation appears to be unfounded.

Research is continuing to refine the epicentre location and the faulting involved to document the onshore historical and geological record of the 1929 event, to research other possible similar events, and to get at the probability of a similar event recurring. The return rate of a large magnitude 7 earthquake in the Laurentian Slope Seismic Source Zone is estimated to be 1000 years but may be as low as 100 years for a magnitude 6 earthquake.

\title{
The 'Bristle Cones' of the ocean: a new palaeo-oceanographic archive found in the solitary deepwater coral Desmophyllum cristagalli from Ophan Knoll
}

\author{
A. Ruffman 1 and P.J. Mudie ${ }^{2}$ \\ IGeomarine Associates Limited, P.O. Box 41, Station M, Halifax, Nova Scotia B3J 2L4, Canada \\ 2 Atlantic Geoscience Centre, Bedford Institute of Oceanography, P.O. Box 1006, \\ Dartmouth, Nova Scotia B2Y 4A2, Canada
}

The use of foraminifera in ocean sediments to date apparent salinity and/or temperature changes recorded in stable isotopes may be limited to a precision of about 1000 years because of the effects of bioturbation which tend to blur the signal. The HUDSON 78-020 cruise, while rock dredging at $1628 \mathrm{~m}$ (uncorrected) on one of the bedrock mounds on top of Orphan Knoll $550 \mathrm{~km}$ northeast of Newfoundland, had a serendipitous recovery of a large collection of dead, Mn-coated, pieces of the solitary ahermatypic coral Desmophyllum cristagalli. The collection lay in the Atlantic Geoscience Centre catacombs for eleven years and was unexamined until 1989. The individual specimens in the collection are in remarkably fine condition despite having laid on the ocean floor for, in some cases, tens of thousands of years. Initial ${ }^{14} \mathrm{C}$ dating, sponsored by Geomarine Associates, INSTAAR, two museums, and the Atlantic Geoscience Centre led to the realization that the collection represented the crossection of a 'graveyard'. The corals are 29,270, 11,525 and 50 y B.P. ( $14 \mathrm{C}$ ages) with U/Th ages recently reported from McMaster University of 4000 to $>70,000$ y B.P. One large pseudocolony appears to have lived from 12,370 to 11,130 y B.P. $\left({ }^{14} \mathrm{C}\right.$ age) from Atlantic Geoscience Centre data, and this spans the beginning of the Younger Dryas glacial event. The McMaster work shows that the top of this colony records a dramatic change in $\delta 180$ of $>2$ per mil, and this was interpreted by J.E. Smith to suggest a rapid shift in the thermohaline circulation at the start of the Younger Dryas over about a fifty-year period. Work is progressing at AGC and MUN to compare the foram isotope stratigraphy from Orphan Knoll cores to the coral data.

Deep-ocean, solitary corals have to some extent been curiosities of the abyss and have a very limited following. However, these corals, which are less susceptible to the effects of bioturbation, sediment transport and variable sedimentation rates, represent a new and potentially extremely valuable archive of palaeo-oceanographic data that can be brought to bear on modern environmental problems through to palaeoclimatic reconstructions. These corals also offer an opportunity to couple ${ }^{14} \mathrm{C}$ and absolute $\mathrm{U}$-series dates to extend the current dendrochronology calibration of the ${ }^{14} \mathrm{C}$ timescale. Over 165 of the coral samples in the collection at AGC remain undated. The Russians have reported deepwater 'coral thickets' off the Grand Banks which are believed to be large 'graveyards' of living colonies of Lophelia prolifera; these too may represent part of the new coral archive. A recent attempt to reoccupy one of these Russian localities came up empty-handed. 


\title{
Late Wisconsinan and Holocene events on the northeast Newfoundland coast and inner shelf
}

\author{
J. Shaw, D.L. Forbes and K.A. Edwardson \\ Atlantic Geoscience Centre, Geological Survey of Canada, Bedford Institute of Oceanography, P.O. Box 1006, \\ Dartmouth, Nova Scotia B2Y 4A2, Canada
}

Grounded glacial ice in Notre Dame Bay formed deposits of acoustically incoherent glacial diamicton up to several tens of metres thick. By 13,000 B.P. the ice had retreated beyond the present coastline, and meltwater plumes were depositing acoustically stratified, glacio-marine, gravelly sandy mud. On the inner shelf the mud was deposited in a draped style and averages $5 \mathrm{~m}$ thick. In fjords the mud occurs as a thick, ponded, basin-fill deposit which contain acoustically transparent intervals interpreted as debris flows. The tops of these fjord sediments date to about 11,500 B.P. In the early- to mid-Holocene, relative sea level dropped to a minimum of about $-17 \mathrm{~m}$ in the east, but probably remained above the present level in White Bay. During and after the low stand, glacial and early postglacial deposits were reworked by waves, currents, and icebergs. Ponded mud was deposited in deep basins, but in the shallow, wave-dominated zone which fringes the outer coast the seabed has a veneer of mobile sand and gravel. This zone is most extensive off the Straight Shore, in the east of the study area, where sheets of gravel ripples occur on the seabed. A large prograded foreland which dates to earlier than 3000 B.P., and a transgressive barrier which stabilised just after 2000 B.P., occur on the Straight Shore. The age and structure of these coastal landforms is related to both inner shelf topography and the pattern of relative sea-level change.

\section{Effects of progressive variation in rifting on lithofacies architecture}

\author{
I.K. Sinclair \\ Canada-Newfoundland Offshore Petroleum Board/University of Aberdeen, Fifth Floor, TD Place, 140 Water Street, \\ St. John's, Newfoundland AIC 6H6, Canada
}

Comparison of the Mesozoic stratigraphic records of rift basins along the North Atlantic Margin suggests that a standard gross pattern of lithofacies architecture may be developed during rifting despite differences in paleoenvironmental settings.

Upper Jurassic and Lower Cretaceous sedimentary fill of the Jeanne d'Arc Basin, Grand Banks, and the Outer Moray Firth Basin, U.K. North Sea, display similar depositional patterns alternating between hydrocarbon source rock and reservoir rock during progressive variations in tectonic activity during a single episode of rifting. Firstly, organicrich marine clays were deposited in restricted anoxic basins during an onset phase of crustal warping. With the onset of brittle extension along active faults, provenance areas became raised and relatively coarse-grained sediments were widely spread over adjacent areas in either fluvial braid plain or submarine fan settings. As rifting peaked, subsidence reached maximums in both rate and areal extent so that basins and basin margins became flooded. Deeper water anoxic conditions and source rock deposition again developed. As rift driven subsidence slowed during the final phase of extension, relative sea-level dropped and provenance areas were again exposed. Consequently, rift basins began to be infilled with coarse coastal plain and submarine sandstone facies, and marine waters returned to a fully oxygenated state. This trend of shoaling of environments culminated in the synchronous development of a mid-Valanginian unconformity in these two widely separated but tectonically-linked basins.

The existence of an underlying common pattern of synrift lithofacies architecture indicates that the tectonic state of a basin provides a basic control on the character and temporal variation of the sea-floor on which sea-bed processes must act.

\section{Seabed geology and processes of the Hibernia and surrounding area, northeastern Grand Bank}

\author{
G.V. Sonnichsen, K. Moran, C.F.M. Lewis and G.B.J. Fader \\ Atlantic Geoscience Centre, Geological Survey of Canada, Bedford Institute of Oceanography, P.O. Box 1006, \\ Dartmouth, Nova Scotia B2Y 4A2, Canada
}

Petroleum discoveries in the Jeanne d'Arc Basin and proposed seabed production facilities for the Grand Bank have heightened the demand for a detailed understanding of the sedimentary and physical properties of near-surface seabed materials, and an understanding of processes affecting seabed stability such as sediment transport and seafloor ice scouring.

Single-channel seismic reflection profiles and borehole investigations show the near-surface to be dominated by a sequence of shallow, seaward-dipping, parallel reflections which are interpreted to have resulted from progradation and aggradation of the continental shelf. At least locally at the Hibernia site, the upper parallel reflection sequence has complex internal reflections arising from dense interbedded sands, silty-clayey sands and minor gravel and cobbles. Zones of clinoform reflections are interbedded within the sequence. The largest zone overlies the Hibernia oilfield and is composed of medium to coarse sand with silt and clay inter- 
beds. It is interpreted as a shallow marine progradational sequence, which may have resulted from meltwater deposition of glacially-eroded sediment. Sediment composition and stability within the progradational sequence varies locally and regionally.

A regional unconformity near the seabed truncates the progradational and parallel reflection units and underlies thin surficial sands and gravels that are periodically trans- ported and reworked by bottom currents, waves and scouring icebergs. Four potential seabed constraints to offshore development are described: (1) sediment transport around seabed installations; (2) sediment liquefaction due to seismic loading; (3) seafloor iceberg scouring, and (4) local and regional variability of foundation sediments and their associated physical properties.

\title{
Fault structure beneath fossil ice keel scour marks
}

\author{
C.M.T. Woodworth-Lynas ${ }^{1}$, J.L. Clark' ${ }^{1}$, and T.J. Calon 2 \\ ICentre for Cold Ocean Resources Engineering (C-CORE), Memorial University of Newfoundland, \\ St. John's, Newfoundland AlB 3X5, Canada \\ 2 Department of Earth Sciences, Memorial University of Newfoundland, St. John's, Newfoundland A1B 3X5, Canada
}

The orientation of conjugate fault sets beneath fossil ice keel scour marks is variable. These faults develop in response to the instantaneous vertical load of a scouring ice keel to produce a non-axisymmetric pattern of shear fractures with normal movement sense. More than one conjugate fault set may develop, although once initiated, stress is more likely to be accommodated by movement along an existing fault set than it is by creating another set.

As a scouring keel moves through the seabed or lakebed sediment any parcel of soil affected by the event will experience changes in stress regime caused by keel loading. Similarly, a scour-induced fault, once initiated, will immediately experience changes in stress orientation. Some faults will be able to continue propagating in their initial orientation as long as resolved shear stress exceeds the yield stress for friction on the fault planes. Alternatively, faults may continue propa- gating in new orientations to enable stress relief to continue, or new faults will develop in response to the new instantaneous load. Structurally speaking, the deformation path results in a messy but explainable fault pattern.

Continuous stress change could thus result in the development of short faults which reflect initiation followed by rapid abandonment as other, more favourably-oriented faults develop. Also, longer faults should exist that have survived by continual changes in propagation orientation and in dip angle as the scouring keel moves forward. Further modification may occur as a result of bulk soil displacements that cause rotation of both locked up and active faults. Such predicted short faults and long faults that exhibit changes in dip and orientation are observed beneath ice keel scour marks.

\section{Soft-sediment striated surfaces and massive diamicton facies produced by floating ice}

\author{
C.M.T. Woodworth-Lynas 1 and J.A. Dowdeswell 2 \\ ICentre for Cold Ocean Resources Engineering (C-CORE), Memorial University of Newfoundland, \\ St. John's, Newfoundland AIB $3 X 5$, Canada \\ 2 Scott Polar Research Institute, University of Cambridge, Cambridge, United Kingdom CB2 IER
}

Soft-sediment striated surfaces, commonly associated with massive diamictites, have been described from many pre-Quaternary glacial sedimentary sequences around the world. A number of authors interpret these associations as evidence for a subglacial origin. However, soft-sediment striated surfaces are formed by the mechanical scouring action of seabed-touching free-floating ice masses over large areas of modern high latitude continental shelves. Prolonged reworking of seabed sediments by scouring ice keels may homogenize sedimentary stratification to form massive diamictons.

In the modern East Greenland glaciomarine environment, massive diamicton has been deposited during the Holocene by the combined action of iceberg rafting and suspension settling from subglacial and seasonal terrestrial meltwater runoff. During deposition continuous scouring by deep-drafted icebergs (up to $550 \mathrm{~m}$ ) has resulted in mechanical mixing of the diamicton. We show that Quaternary ice keel scour processes have affected an order of magnitude more of the seafloor than have subglacial processes, and suggest that this order of magnitude difference probably can be applied also to pre-Quaternary glacial marine and lacustrine environments. Consequently, the effects of ice keel scour should be more frequently preserved than features of ice shelf grounding zone processes. Field work directed at reappraising preQuaternary soft-sediment striated surfaces associated with diamictites now may be appropriate. 


\title{
GEOLOGICAL ASSOCIATION OF CANADA NUNA CONFERENCE
}

\section{NEW PERSPECTIVES IN THE APPALACHIAN- CALEDONIAN OROGEN}

\author{
ABSTRACTS OF PAPERS PRESENTED \\ AT A CONFERENCE IN HONOUR OF \\ DR. HAROLD WILLIAMS
}

\section{AUGUST 12.13, 1994 GRAND FALLS, NEWFOUNDLAND}

The Geological Association of Canada Nuna Conference New Perspectives in the Appalachian-Caledonian Orogen was held in honour of Dr. Harold (Hank) Williams. The conference was intended not as a comprehensive review of the orogen, but rather as an interim report on the most recent developments in the ongoing study of the mountain belt. For more than three decades Hank has mapped, compiled and expounded upon the Appalachian-Caledonian orogen; the conference is indelibly stamped with his legacy. The organization of oral presentations reflects the symmetry that Hank first recognized in the Newfoundland Appalachians thirty years ago in his influential paper The Appalachians in northeastern Newfoundland - A two-sided symmetrical system, and is here manifest as the Laurentian margin, the oceanic tract and the peri-Gondwanan margin.

Hank's world has been Newfoundland-centred, being the native son he is; however, he has always used the Rock as a base and looked beyond geographic boundaries to the big picture. In this style, nearly one half of the abstracts here are based on Newfoundland data, with the remaining contributions ranging from Scandinavia to the British Isles and through to the southernmost Appalachians. Most of the presentations dealt with crustal elements that Hank first recognized in Newfoundland and that only became consolidated in our thoughts with his landmark Tectonic Lithofacies Map of the Appalachian Orogen in 1978. Nary an abstract is presented that does not make some allusion to this broad-scale zonation of the orogen, or its extrapolation into Europe.

Hank has led many a dwarf-line since they came in vogue in 1975; we have all been dwarves in his line of regional Appalachian-Caledonian geology. With this conference, we say thanks to Hank for all of his contributions to our science and for all of the fiddlin' around along the way.

$\begin{array}{ll}\text { Conference Organizers: } & \text { Jim Hibbard } \\ & \text { Cees van Staal } \\ & \text { Peter Cawood } \\ & \text { Steve Colman-Sadd }\end{array}$


Tectonic significance of high-pressure metamorphic rocks and dextral strike-slip faulting in the southern Appalachians

\author{
M.G. Adams, K.G. Stewart, C.H. Trupe and R.A. Willard \\ Department of Geology, University of North Carolina at Chapel Hill, Chapel Hill, North Carolina 27599-3315, USA
}

The occurrence of an eclogite-bearing suture zone in the southern Blue Ridge of northwestern North Carolina, marked by a dextral transpressional shear zone, constrains tectonic models for the evolution of the Appalachian orogen. This suture zone defines the contact between the eastern and western Blue Ridge, separating rocks of distinct oceanic affinities (metapelite, metagraywacke, metabasite, ultramafic rocks and eclogite) from Grenville-age gneisses of the Laurentian continent. Eclogite facies metamorphism resulted from subduction of oceanic crust, eventually leading to the closure of Iapetus and the subsequent Taconic orogeny. The collision produced an amphibolite facies overprint on the eclogite and regional amphibolite facies metamorphism in the eastern Blue Ridge and adjacent parts of the Laurentian basement. Reported isotopic ages record both Taconic and Acadian metamorphism from both sides of the suture.

The Taconic compressional event produced documented northwest-directed thrusts; however, Acadian structures in the eastern Blue Ridge are more equivocal. Sub-horizontal, mineral-stretching lineations in amphibolite facies mylonites from the suture indicate strike-slip movement under high- grade conditions. Kinematic indicators from mylonites show dextral shear sense, in contrast to northwest-directed thrusting previously attributed to this contact. Late Silurian to early Devonian pegmatites are both sheared and cross-cut the mylonites, constraining the time of strike-slip faulting to be Acadian. Later Alleghanian faulting locally overthrust, or reactivated, the suture.

Other workers have correlated this contact as part of a suture extending the length of the Appalachian orogen (e.g., Hayesville fault, Camerons line, Brompton-Baie Verte line). Parts of this suture show pre-Alleghanian dextral strikeslip motion. Recently proposed plate reconstructions, based on stratigraphic, paleontologic, and paleomagnetic data, show Taconic subduction and collision of Laurentia and South America, followed by Acadian dextral transpression. This model predicts Acadian metamorphism and dextral strikeslip faulting along the Taconic suture. Our structural and metamorphic data, combined with the work of others along correlative parts of this suture, provide strong support for this tectonic model.

\title{
A model for terrane accretion in Cape Breton Island, Nova Scotia, and its implications for tectonic evolution of the northern Appalachian orogen
}

\author{
S.M. Barr, R.P. Raeside, B.V. Miller and C.E. White \\ Department of Geology, Acadia University, Wolfville, Nova Scotia BOP IXO, Canada
}

Geological, geophysical, chronological, and chemical data support the interpretation that terranes in Cape Breton Island correspond to those in Newfoundland, and that Cape Breton Island, like Newfoundland, preserves vestiges of the Laurentian margin and varied accreted terranes related to the "Gondwanan" continents. As in Newfoundland, the original relations among these accreted terranes and the timing of their accretion are enigmatic because of post-accretionary transpressive and transtensional adjustments. However, constraints are provided mainly by contrasts and similarities between now adjacent terranes. U-Pb geochronology reveals no links between the Humber-equivalent Blair River Complex and adjacent Aspy terrane until ca. $430 \mathrm{Ma}$, and isotopic studies do not show evidence for Grenville-type crust under Aspy terrane, even in the Devonian. Plutonism and high-grade metamorphism in the Blair River Complex and approximately synchronous volcanism and plutonism in the Aspy terrane may record juxtaposition by subduction. Devonian peak metamorphic conditions and syncollisional plutonism in the Aspy terrane are interpreted to reflect transpressional docking of the Aspy and Bras d'Or terranes, with the Bras d'Or terrane over-riding Aspy. Juxtaposition of the Bras d'Or terrane and Mira terrane (Avalon sensu stricto) was accomplished by the Early Carboniferous, but differences in Cambrian-Ordovician history indicate that at least the now-adjacent parts of the Bras d'Or and Mira terranes were not adjacent at that time.

\section{Collisional tectonics along the Appalachian margin of Laurentia: constraints from Corner Brook Lake and Baie Verte}

\author{
P.A. Cawood 1, G.R. Dunning2, J.A.M. van Gool 2 and D. Lux 3 \\ ISchool of Applied Geology, Curtin University, G.P.O. Box U1987, Perth, W.A. 6001, Australia \\ 2 Department of Earth Sciences, Memorial University of Newfoundland, St. John's, Newfoundland A1B 3X5, Canada \\ 3 Department of Geological Sciences, University of Maine, 119 Boardman Hall, Orono, Maine 04469-1001, USA
}

Corner Brook Lake and western Baie Verte lie within the internal domain of the Appalachian Humber Zone and define the eastern surface extent of Laurentia. To the east are accreted oceanic and continental terranes. High grade 
metamorphism and polyphase deformation of the Laurentian margin has "historically" been attributed to Ordovician Taconian overthrusting of these outboard terranes. However, $\mathrm{U} / \mathrm{Pb}$ and Ar/Ar dating of a variety of igneous and metamorphic mineral phases indicate an Early Silurian age for orogenesis.

At Corner Book Lake, a lower limit on deformation is provided by a $\mathrm{U} / \mathrm{Pb}$ zircon age of $434+2 /-3 \mathrm{Ma}$ for a pegmatite that is affected by the regional foliation and is interpreted to be syntectonic. A garnet-kyanite-staurolite schist, which records peak metamorphic conditions and in which porphyroblasts overgrow the regional foliation, gave $\mathrm{U} / \mathrm{Pb}$ ages of $430 \pm 2 \mathrm{Ma}$ for monazite and $437 \pm 6 \mathrm{Ma}$ for rutile. Ar/Ar cooling ages for hornblende from amphibolites are $427 \pm 3 \mathrm{Ma}, 425 \pm 3 \mathrm{Ma}$, and $424 \pm 4 \mathrm{Ma}$, and muscovite from psammitic and pelitic schists are $429 \pm 3 \mathrm{Ma}, 427 \pm 3$ $\mathrm{Ma}, 423 \pm 4 \mathrm{Ma}$, and $413 \pm 3 \mathrm{Ma}$.

At Baie Verte, monazite from a syntectonic leucogranite melt within a psammite from the Fleur de Lys Supergroup yielded a precise concordant $\mathrm{U} / \mathrm{Pb}$ age of $427 \pm 2 \mathrm{Ma}$. Monazite from the muscovite-garnet bearing syntectonic S-type phase of the Wild Cove igneous suite gave an identical age (427 \pm $2 \mathrm{Ma}$ ). Zircon and titanite from a K-feldspar, megacrystic, posttectonic I-type pluton of the suite indicate an age of crystallization of $423 \pm 3 \mathrm{Ma}$. Ar/Ar data from the Fleur de Lys Supergroup gives ages as old as $429 \pm 10 \mathrm{Ma}$ for hornblende and $421 \pm 10 \mathrm{Ma}$ for muscovite.

The isotopic data from the Corner Brook Lake and Baie Verte regions are remarkably uniform and indicate that regional deformation, metamorphic mineral growth and cooling of this segment of the eastern margin of Laurentia occurred in the Early Silurian between 435 and $425 \mathrm{Ma}$. The U/Pb and $\mathrm{Ar} / \mathrm{Ar}$ data require that rapid subduction of the margin was followed by equally rapid eduction. A Silurian age for deformation and metamorphism of the Laurentian margin is coincident with the timing of similar events along the Newfoundland Gondwana margin and suggests that the Silurian was a period of major continent-continent collision.

\title{
Tectonostratigraphic development of the northeastern extremity of the Dunnage Zone in Newfoundland
}

\author{
K.L. Currie \\ Geological Survey of Canada, 601 Booth Street, Ottawa, Ontario K1A 0E8, Canada
}

The type area of the Dunnage Zone is bisected by the Dog Bay Line. East of the Dog Bay Line, structural elements predate a sub-Llandovery unconformity, except for a single period of upright folding. West of the line, structures are mainly post-Llandovery, and northwest-verging. Stratigraphy of thrust slices emplaced east of the line in post-Caradoc time can be directly correlated to formations west of the line. These relations require eastward obduction in Arenig time followed by arc-rifting with initial melange formation and subsequent volcanism and sedimentation from the late Arenig to Caradoc time. Closure of the rifted basin, with renewed eastward thrusting, trench-filling and structural inversion began in Ashgill time, but the basin was suffi- ciently wide in the Llandovery that contrasting Silurian successions formed on opposite sides. Final basin-closing along the Dog Bay Line in late Silurian time, coincided with the onset of major metamorphism and granitoid plutonism. Late warping of the line may indicate closure by collision with a promontory of North America. The data suggest consumption of this part of the Iapetus Ocean entirely by westward subduction. Post-Caradoc magmatism was of non-arc type, resulting from some combination of delamination, rifting and tectonic overthickening. These conclusions apply to the Exploits Subzone only, but the Notre Dame-Exploits subzone boundary exhibits no obvious tectonostratigraphic consequences.

\section{Stratigraphy, sedimentology and geochemistry of the Cottrells Cove Group (Buchans-Robert's Arm volcanic belt): implications for terrane boundaries in the Dunnage Zone}

\author{
T. Decl, S.H. Swinden 1 and G.R. Dunning 2 \\ 1 Geological Survey Branch, Department of Mines and Energy, \\ P.O. Box 8700, St. John's, Newfoundland AIB 4J6, Canada \\ 2 Department of Earth Sciences, Memorial University of Newfoundland, \\ St. John's, Newfoundland A1B 3X5, Canada
}

The Cottrells Cove Group constitutes a significant component of the Buchans-Robert's Arm volcanic belt (Notre Dame Subzone). It is broadly correlated with the Robert's Arm Group to the west and with the Chanceport Group to the east. The Cottrells Cove Group is represented by volcano-sedimentary rocks of the Fortune Harbour Formation and by conformably overlying sedimentary rocks of the Moores Cove Formation. The lowest N-MORB pillow and massive lavas of the Fortune Harbour Formation are in a possible conformable relationship with the underlying pillow lavas of the Moretons Harbour Group. The Chanceport Fault, previously recognized as a regional dislocation and terrane boundary, outcrops as one of many faults affecting the Cottrells Cove Group, rather than a boundary separating distinctive geologic units.

The younger, thrust-bound sections of the Fortune Harbour Formation consist of younger, island-arc lavas, followed by a 1250-m-thick succession of radiolarian cherts and volcaniclastic deposits, representative of an oversupplied basin plain. A felsic tuff from this sedimentary unit has a $U / P b$ 
zircon age of $484 \pm 2 \mathrm{Ma}$. E-MORB pillow lavas and the overlying radiolarites are considered the youngest rocks of the Fortune Harbour Formation. The overlying Moores Cove Formation is represented by an undated, coarsening-upward succession of lower-slope/basin-plain and submarine-fan deposits, and contains in the upper part detritus reminiscent of the Upper Ordovician-Lower Silurian deep-sea tur- bidites of the Exploits Subzone. A possible correlation of the Moores Cove Formation across the Red Indian Line with the turbiditic deposits of the Point Leamington and the Milliners Arm formations, undermines the fundamental stratigraphic criteria for distinguishing Late Ordovician-Early Silurian developments in the Notre Dame and Exploits subzones.

\title{
Late Precambrian-Earty Cambrian orogeny in the South Carolina piedmont
}

\author{
A.J. Dennis 1 , J.E. Wright ${ }^{2}$ and D.T. Secor ${ }^{3}$ \\ IDepartment of Geology, University of South Carolina at Aiken, Aiken, South Carolina 29801, USA \\ 2 Department of Geology and Geophysics, Rice University, Houston, Texas 77251, USA \\ 3 Department of Geological Sciences, University of South Carolina, Columbia, South Carolina 29208, USA
}

New $\mathrm{U} / \mathrm{Pb}$ zircon dates and re-examination of map patterns strongly suggest a Late Precambrian-Early Cambrian orogenic event in the Carolina Terrane of South Carolina. This event is expressed in greenschist to amphibolite facies metamorphism and a regionally extensive schistosity or cleavage. In Spartanburg and Union Counties, we have dated deformed and metamorphosed and undeformed, unmetamorphosed plutons: two strongly foliated, metagranodiorites yield crystallization ages of $579 \pm 4$ and $571 \pm 16 \mathrm{Ma}$. These plutons intrude metamafic volcanic rocks, and appear to contain all the fabric elements carried by the metavolcanic rocks. Heterogeneously deformed Means Crossroads complex metadiorite yields a crystallization age of $538 \pm 5 \mathrm{Ma}$. An undeformed, post-metamorphic diorite intrudes the contact between Mean Crossroads metadiorite and mafic metavolcanic rocks. This pluton contains abundant equidimensional mafic enclaves and carries no solid state fabric. Two samples from this pluton yield crystallization age of $535 \pm 4$ and $541 \pm 8 /-4 \mathrm{Ma}$. The oldest $206 \mathrm{~Pb} * / 238 \mathrm{U}$ from the latter indicates the minimum age for this pluton is $537 \mathrm{Ma}$. We interpret these data to indicate a deformation and metamorphic event $c a .570$ to $537 \mathrm{Ma}$. In Kershaw County, the Longtown metagranite is heterogeneously deformed but not as strongly deformed as the Persimmon Fork Formation it intrudes: this may reflect contrasting rheology or grain size; it may also be that the pluton was intruded relatively late in the deformation. The Longtown metagranite yields a crystallization age of $\mathbf{5 5 0}$ Ma. In Lexington County, the trilobite-bearing, upper mudstone unit of the Asbill Pond formation is interpreted to lie in angular unconformity above the lower parts of the Asbill Pond. Middle Cambrian trilobites recovered from this unit are weakly deformed or undeformed. We interpret these data to indicate deposition of the upper trilobite-bearing mudstone following the 570 to $537 \mathrm{Ma}$ event. We believe this unit represents the youngest preserved Paleozoic strata in the Piedmont of the Carolinas and Georgia (post-Richtex, post-Ablemarle Group). Therefore, the orogeny predates accretion of the Carolina Terrane to Laurentia: the Asbill Pond fauna is an Acado-Baltic assemblage that accumulated on the fringes of Gondowana. Hence, we believe that the structures and metamorphism we describe here are related to intra-arc rifting or changes in convergent plate boundary kinematics, or both, and not to be accretion of the Carolina arc to Laurentia.

\section{The evolution of the Clew Bay Fault Zone (Baie Verte-Brompton Line) and associated zones in western Ireland}

\author{
J.F. Deweyl and P.D. Ryan 2 \\ IUniversity of Oxford Parks Road, Oxford OXI 3PR, United Kingdom \\ 2 University College Galway, Galway, Ireland
}

The provocative and geographically inept title of the paper is to allow and emphasize some comparisons between Lower Paleozoic structures, lineaments, ophiolitic "suture zones", arcs and sinistral transpressional systems in Newfoundland and Ireland, especially to contribute to the debate about the relative importance and roles of Ordovician versus Siluro-Devonian deformation in the structural evolution of the international northwestern zones of the Maritime Appalachians and British Caledonides.

The Deer Park and Westport complexes crop out in the Clew Bay region, western Ireland and form, we believe, the suture zone between an Ordovician island arc to the south and the Laurentian continental margin. The Deer Park Complex comprises an ophiolitic mélange with knockers of dolerite, sheeted dykes, dolerite-mylonites, static gabbros, ultramafic cumulates, mantle harzburgites, serpentinite breccias and amphibolite-ultramylonites set in a serpentinite or talc-carbonate matrix. This lithological assemblage is characteristic of an ophiolitic backstop thrust located in the hanging wall of a subduction zone nucleated at a transform fault like the Coastal Complex of the Bay of Islands Complex. The Westport Complex contains three components: (1) highly sheared Lower Ordovician muds, silts, sands, dolomites, cherts and microconglomerates of low metamorphic grade; (2) quartz ribbon mylonitic metasediments; and (3) meta-basic volcanites and brecciated serpentinites locally containing crossite. Geographic proximity, structural style and stacking are consistent with a common origin in a subduction-accretion prism 
formed against the Deer Park backstop. These complexes are preserved at the site of Llanvirn collision of an arc with the Laurentian Foreland and represent an eastward continuation of the Baie Verte-Brompton Line in Newfoundland. To the south, the South Mayo Trough, a broad synclinorium containing a 10-km sequence of Early Ordovician turbidites passing up into shallow water sandstones is interpreted as a forearc basin with an ophiolitic basement that formed a backstop to an accretionary prism on the northern edge of the northfacing arc. The South-Mayo Trough was fed principally by arc and ophiolite-derived clastics during the Arenig with an increasing metamorphic component during the Llanvirn. Prior to the late Llandovery, sinistral transcurrent faulting transposed the Connemara Dalradian terrane to its present position on the "outboard" oceanward side of the South Mayo Trough. The Late Ordovician transpressional "docking" of Connemara provided the southerly source for high-grade metamorphic clasts in the Deeryveeny Formation.

Regional sinistral transpression generated much of the structure of a broad zone between South Achill/Southeastern Ox Mountains and north Connemara that includes the Clew Bay Zone during the late Silurian. Subhorizontal stretching is dominant in clockwise transecting cleavage sequences with shortening from $25 \%$ to $75 \%$ and $\mathrm{K}$ values from about 0.1 to 1.0 ; therefore, the bulk transpressional displacement direction was over about $70^{\circ}$ from the normal to the boundaries of the deforming zone, and all structures are strongly non-coaxial. Transpression was partitioned strongly in space and time in different parts of the broad zone. In the north, penetrative sinistral shearing is superimposed on earlier dextral transpressive structures and fabrics in South Achill and the Southeastern Ox mountains. The Ox Mountains granodiorite/tonalite Complex was emplaced "lit par lit" in a sinistral pull-apart while the Ladies Brae Fault Zone developed as a "compressional jog thrust". The Clew Bay Zone developed distributed sinistral shear principally in Ordovician serpentinites as the Louisburgh Basin opened as a lozengeshaped pull-apart with a major shear zone (Emlagh Pt. Zone) along its southern margin. To the south, the South Mayo Trough shows a multiple-clockwise-transecting cleavage sequence related to transpressional shortening and progressive flexure that induced cleavage "refraction" and increasingly steep bedding/cleavage intersection. Early fuchsite (after chromite) shear zones are controlled stratigraphically and are deformed by a clockwise-transecting second cleavage with rare minor S-folds. During flexural steepening, cleavage continued to form in pelites while early formed cleavages in psammites opened vertically to generate quartz vein arrays. Bulk vertical stretching was followed by vertical shortening with gravitationally-controlled flow to the south and north from a transpressional high through the Sheeffry Mountains. Late sinistral shear allowed the intrusion of the Corvock "granite" into a rhomb-shaped sinistral pull-apart. Bedding plane slickensides are partitioned into vertical flexural slip and horizontal sinistral lineations. Partitioning between pure sinistral strike-slip and transpression occurs at all scales from the map to the outcrop. Rotations, as demonstrated by palaeomagnetic data, show the expected anticlockwise with vorticity, but also clockwise, which may be related to motion along sinuous strike-slip faults and/or orientation of passive marker blocks with respect to the instantaneous transpressional displacement direction.

A principal conclusion is that late Silurian structures overprint and, locally, mask Ordovician structures, but that the Clew Bay Fault Zone and the Baie Verte-Brompton Line represent an arc-continental margin collision zone along the line of north-facing early Ordovician subduction zone, from which northwest ward ophiolite obduction occurred.

\title{
The relationship between migmatization and granite magmatism in the northeastern Gander zone: evidence from Sm-Nd isotopic characteristics
}

(poster)

\author{
R. D'Lemos 1 , T. Kingl and R. Holdsworth 2 \\ IDepartment of Geology, Oxford Brookes University, Headington, Oxford OX3 OBP, United Kingdom \\ 2 Department of Geological Sciences, University of Durham DHI 3LE, United Kingdom
}

Focussed zones of high grade metamorphism, migmatization and granite plutonism are key elements of the Ordovician-Silurian evolution of the northeastern Gander zone of Newfoundland. High temperature-low pressure migmatization was the result of both regional metamorphism within transpressional shear zones and locally advected heat from plutons. Sm-Nd isotopic characteristics of metasedimentary rocks, gneisses and intrusive granitoids place some constraints upon their origins. A marked similarity in $\varepsilon_{\mathrm{Nd}}(-8$ to -6$)$ for low grade Gander Group metasediments and sillimanite bearing paragneisses of the Hare Bay Gneiss are most consistent with derivation from the same protolith sedimentary sequence. Despite some open system behavior, these isotopic signatures can be traced into zones of local (contact) and regional migmatization and partial melting, fingerprinting the upper crustal contribution to granite magmatism. Voluminous Silurian megacrystic granites $\left(\varepsilon_{\mathrm{Nd}}-5\right.$ to 0$)$ were not derived from such a source, nor were they derived exclusively from the mantle. The most likely source was lower crust and mantle, variably contaminated by mid- to upper crust, $\varepsilon_{\mathrm{Nd}}$ characteristics resulting from systematic changes in relative contributions through time. Pre-Silurian metasedimentary sequences and orthogneisses, and Silurian-Devonian intrusive granites of the northeastern Gander zone contrast with those of the Dunnage, Humber, and Avalon zones confirming fundamental differences in the underlying crustal blocks and palinspastic separation prior to terrane assembly. 


\title{
Collisional tectonics in the Humber zone of the Vermont-Quebec Appalachian orogen (poster)
}

\author{
B.L. Doolan 1 and M. Colpron 2

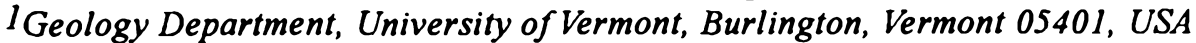 \\ 2 Department of Geological Sciences, Queen's University, Kingston, Ontario K7L 3N6, Canada
}

The southern Quebec-northern Vermont segment of the Quebec reentrant is characterized by a distinct structural style, which contrasts markedly from that of western New England to the south. Taconian structures in southern Quebec, and adjacent Vermont, are dominated by east-verging folds and thrust faults associated with crustal delamination. Recent field work in this part of the Appalachian orogen provides the basis for interpreting the structural evolution and the crustal scale deformation mechanism within the Humber zone, during the Taconic orogeny.

Three "phases" of deformation are recognized throughout the internal parts of the Quebec-Vermont Humber zone. The earliest structures $\left(D_{1}\right)$ are characterized by a pervasive composite foliation, associated with west-verging thrust faults and recumbent folds. Metamorphic soles underlying Eden Mills and Thetford Mines ophiolites ( $c a .480 \mathrm{Ma}$ ) constrain the age of earliest deformation recognized within the Humber zone. To the west, timing of early deformation is constrained by involvement of the outer shelf Melbourne Formation (midArenig to Llanvirn) in $D_{1}$ folds. This deformational event is associated with metamorphism which grades from amphibolite facies in the core of the Sutton-Green Mountains, to lower greenschist in the Oak Hill Group to the west. Early structures are superposed by a second set of folds and faults $\left(D_{2}\right)$ that define the structural fan characteristic of this segment of the Appalachian orogen. We relate these structures to the introduction of a tectonic wedge (Sutton-Green Mountains) underneath supracrustal rocks of the Oak Hill Group. This process produces a supracrustal high-strain zone, characterized by east-verging thrusts, between these two domains (Mansville Complex). These structures are syn- to post-peak metamorphism throughout most of the internal domain. A Taconian age is indicated by $40 \mathrm{Ar} / 39 \mathrm{Ar}$ hornblende cooling age of ca. $439 \mathrm{Ma}$ for the Oak Hill Group.

The location of the Mansville Complex (and of the fan axis) coincide with abrupt facies change in the sedimentary sequence and the disappearance of the Tibbit Hill volcanics. We suggest that these features are related to Early Cambrian rifting, and may have controlled the development of the $\mathrm{D}_{2}$ structural fan during the Middle Ordovician Taconic orogeny. Late structures $\left(D_{3}\right)$ are related to arching of the Sutton-Green Mountains anticlinorium. Intense deformation along, and east of the Baie Verte-Brompton zone may be related to this deformational event, therefore constraining $\mathrm{D}_{3}$ as an Acadian event.

\section{Deformational events and their timing along the Cape Ray Fault, Newfoundland Appalachians}

\author{
B. Dubél, K. Lauziere 1, G. Dunning 2 and C. Roddick ${ }^{3}$ \\ 1 Quebec Geoscience Centre, Sainte-Foy, Canada \\ 2 Department of Earth Sciences, Memorial University of Newfoundland, St. John's, Newfoundland AIB 3X5, Canada \\ 3 Geological Survey of Canada, 601 Booth Street, Ottawa, Ontario K1A 0E8, Canada
}

The Cape Ray Fault Zone (CRFZ) is a major fault zone in southwestern Newfoundland located at or close to the boundary between composite Laurentia and composite Avalonia, and represents an important structural feature in the understanding of the Appalachian orogen. Detailed structural analysis along a $60 \mathrm{~km}$ long segment of the CRFZ provide evidence for a complex structural history. The CRFZ recorded reversesinistral thrusting of deeper crustal rocks of the Grand Bay Complex at amphibolite grade, followed by a protracted collisional event characterized by reverse-dextral motion and retrogression to greenschist facies of the Grand Bay Complex rocks thrust on to supracrustal rocks of the Windsor
Point Group. This complex structural history occurred over a short period of time between Late Silurian and Early Devonian. Strain partitioning generated by the interaction between pluton-related and tectonic-related strain fields brought about orogen-parallel transcurrent shearing during the later stages of the collision. Younger deformation include sinistral transcurrent shearing and an extensional event, postdating late tectonic granites. The east-west flexure of the CRFZ represents a tear fault which accommodated differential shortening between the northeast-oriented segment of the CRFZ and the correlative Red Indian Line (RIL) or Noel Paul's Line (NPL) located further to the north-east. 


\title{
Brachiopods as indicators of early Ordovician paleogeography
}

(poster)

\author{
D.A.T. Harper1, C.M. Niocall1, R.B. Neuman 2 and S.H. Williams 3 \\ 1 Department of Geology, University College, Galway, Ireland \\ 2Department of Paleobiology, MRC 137 National History Museum, Smithsonian Institution, \\ Washington, DC 20560, USA \\ ${ }^{3}$ Department of Earth Sciences, Memorial University of Newfoundland, St. John's, Newfoundland AIB 3X5, Canada
}

The distinctiveness of and contrasts between the early Ordovician (Arenig-Llanvirn) Celtic and Toquima-Table Head brachiopod provinces has been demonstrated repeatedly by statistical comparisons since their introduction more than 20 years ago. Several new occurrences in the Appalachian orogen in Canada and the Caledonides of the British Isles and Scandinavia, and the use of microcomputer-based statistical techniques extravagantly reaffirm these faunal contrasts. Strong paleogeographic linkages between Celtic and Gondwanan assemblages and between the contrasting ToquimaTable Head and Laurentian assemblages are documented in cladogram and dendrogram plots based on a number of distance and similarity coefficients. Principal Component and Correspondence analyses show similar patterns. The midto high-latitude, cool-water Celtic-Gondwanan environments are also distinguished by the nature of their sedimentary rocks, their geologic context, and recently obtained paleomagnetic data, in contrast to those in low-latitude warmwater peri-Laurentian settings. These data are essential components in evaluating and compiling Ordovician paleogeographic maps.

\section{The status of the Great Glen Fault, Scotland}

\author{
T. Harris \\ Department of Earth Sciences, University of Liverpool, P.O. Box 147, Brownlow Street, \\ Liverpool L69 3BX, United Kingdom
}

To the northwest of the northeast-trending Great Glen Fault, polyphase deformation of Moine metasedimentary rocks involved Precambrian subrecumbent, north-northwest facing, curvilinear nappe folds reworked by Ordovician-Silurian north-northeast-trending, upward-facing upright folds. Both episodes of deformation were accompanied by greenschistmid-amphibolite facies Barrovian metamorphism. To the southeast of the fault, the Dalradian succession, the oldest part of which is lithologically strikingly similar to the Moine, has undergone a geometrically remarkably similar structural history, also involving lower Paleozoic reworking of Precambrian nappes. However, somewhat sparse isotopic evidence derived from opposite sides of the fault points to con- trasts in the age of the nappe-forming episodes of as much as $400 \mathrm{Ma}$. There is some evidence that it occurred at $1000 \mathrm{Ma}$ to the northwest of the fault, and better evidence that it occurred $\sim 600 \mathrm{Ma}$ to the southeast. There is much less contrast in the age of Caledonian reworking of the nappes on either side of the fault. It possibly began in the midOrdovician to the northwest, but in the early Ordovician to the southeast. The waning of Caledonian orogenesis appears to have occurred everywhere in the late Silurian-early Devonian. Does the Great Glen separate far-traveled terranes, largely juxtaposed by the early Devonian, or are the contrasts in age more apparent than real?

\section{Geochronology and regional tectonic implications of Silurian deformation in the Nashoba Terrane, southeast New England}

\author{
J.C. Hepburn 1 , G.R. Dunning 2 and R. Hon 1 \\ IDepartment of Geology and Geophysics, Boston College, Chestnut Hill, Massachusetts 02167, USA \\ 2 Department of Earth Sciences, Memorial University of Newfoundland, St. John's, Newfoundland A1B 3X5, Canada
}

The Nashoba Terrane is fault-bounded and lies between the Avalon Terrane immediately to the east and the Acadiandeformed Merrimack Belt (Kearsarge-Central Maine Synclinorium-KCMS) to the west. Recent $\mathrm{U} / \mathrm{Pb}$ age determinations and geochemical data from metavolcanic and intrusive rocks within the terrane have provided a new perspective on the tectonics of this terrane and the role it played in the evolution of the eastern margin of the Appalachian orogen during the mid-Paleozoic.

The Fish Brook Gneiss, previously interpreted as Precambrian basement, has yielded a Cambro-Ordovician U/ $\mathrm{Pb}$ abraded zircon crystallization age of $499 \pm 6 /-3 \mathrm{Ma}$. This date constrains the age of the metavolcanic and metasedimentary rocks of the terrane to the interval between late Cambrian 
and early Silurian. Geochemical signatures from the mafic metavolcanics indicate the Nashoba Terrane was a magmatic arc during at least part of this time period.

During the Silurian, the Nashoba Terrane underwent multiple deformation, metamorphism to the sillimanite-Kfeldspar zone and intrusion by two types of magmas, calcalkalic diorite-granite and peraluminous granite. Monazite from Fish Brook Gneiss gives an age for the metamorphism of $425 \pm 2 \mathrm{Ma}$. A crystallization age for the younger phase of the Andover Granite, thought to be anatectically produced during the metamorphism, was determined by U/Pb on zircon to be $412 \pm 2 \mathrm{Ma}$.
The Nashoba Terrane and consequently the eastern margin of the Appalachian orogen in southeast New England experienced a major orogenic event during the mid-Silurian, much earlier than the timing of the traditional "Acadian" deformation to the west. The orogenic cycle began earlier in the east as the Nashoba Terrane, along the leading edge of the converging eastern block, impinged (perhaps obliquely) upon the KCMS in the early-to mid-Silurian, well prior to the docking of Gondwana. The deformational front initiated at this time subsequently migrated to the west and northwest during the next $50 \mathrm{Ma}$, culiminating in the Acadian orogenic phase of west-central New England.

\title{
Developing model for the southern Appalachians
}

\author{
J. Hibbard \\ Department of Marine, Earth and Atmospheric Sciences, North Carolina State University, \\ Raleigh, North Carolina 27695, USA
}

The southern Appalachian orogen comprises three firstorder tectonic elements; Laurentia is separated from the periGondwanan Carolina Terrane to the east by the Piedmont composite terrane. The Laurentian margin records the development of a Cambrian-Ordovician passive margin. The adjacent Piedmont terrane comprises a poorly known late Precambrian (?) to Paleozoic amalgam of metaclastic, metavolcanic, and plutonic rocks and orthogneiss. The Carolina Terrane is a late Precambrian-Cambrian volcanic arc sequence.

The oldest post-Grenville accretionary event appears to be a ca. 605 to $535 \mathrm{Ma}$ deformation recorded along the western edge of the Carolina Terrane. Isotopic studies indicate that this event may record the overriding of a more evolved crustal block by the more juvenile Carolina Terrane. Alternatives for the footwall block include: (i) the Piedmont terrane, (ii) the Grenvillian Goochland terrane, or (iii) a crustal block that has departed the orogen. A Cambrian tectonothermal event is recorded in the Piedmont terrane; unabated development of the passive margin sequence precludes the involvement of Laurentia in this event.

Initiation of the Taconic orogeny is recorded by the Blountian clastic wedge on the Laurentian margin; a younger Ordovician unconformity is found at the base of the ArvoniaQuantico sequence in the Piedmont terrane. The Taconic appears to record the interaction of at least the Piedmont terrane with Laurentia. Available evidence for mid-Paleozoic deformation hints at a strike-slip dominated event, possibly between the Piedmont and Carolina terranes. Appalachian accretionary activity terminated with the Alleghanian collision of Africa with Laurentia; this event remobilized most earlier major boundaries.

\section{The consequences and possible causes of deformation partitioning in the Gander Lake Subzone, northeast Newfoundland}

\author{
R.E. Holdsworth ${ }^{1}$ and R. D'Lemos ${ }^{2}$ \\ 1 Department of Geological Sciences, University of Durham, Durham DHI 3LE, United Kingdom \\ 2 Department of Geology, Oxford Brookes University, Oxford $O X 3 \mathrm{OBP}$, United Kingdom
}

In common with most of the Central Mobile Belt in Newfoundland, the Gander Lake Subzone displays rapid variations in structural complexity, metamorphic grade and intensity of igneous intrusion. Some of these complexities reflect the successive accretion episodes that occurred during closure of Iapetus, but this study will illustrate that substantial variations can arise due to more localized controls. During the mid-Silurian, sinistral-oblique collision occurred between the Avalon Composite Terrane and the Laurentian margin. The resulting deformation profoundly affected substantial regions of the Gander Group and was progressively localized into two kilometre-scale, sub-vertical belts of high strain: the Wing Pond and Hare Bay Gneiss shear zones. As the focusing of deformation develops, sequential cycles of overprinting and transposition are recognized, together with kinematic partitioning of the regional transpressional strain into strike-slip and dip-slip dominant regions. Both shear zones also coincide exactly with focused belts of syn-tectonic igneous intrusion and markedly higher metamorphic grade \pm regional melting of the Gander Group. This suggests that the localization and kinematic partitioning of strains reflects rheological weakening within shear zones due to higher temperatures resulting from either shear heating and/ or fluid fluxing from greater depths. These processes appear to be associated with, or to be responsible for the generation and upward channeling of magmas derived initially from a lower or sub-crustal source. Thus, prior to any regional-scale (i.e., late tectonic) interpretation of geological sequences observed in a set of outcrops, it is necessary to consider the additional complexities that may arise due to the interactions of deformation, metamorphism and syn-tectonic magmatism within shear zones. 


\title{
Arc rivals of the Taconian orogeny in western New England
}

\author{
P. Karabinos 1 , H.M. Stoll 1 and J.C. Hepburn 2 \\ IDepartment of Geology, Williams College, Williamstown, Massachusetts 01267, USA \\ 2 Department of Geology and Geophysics, Boston College, Chestnut Hill, Massachusetts 02167, USA
}

Tectonic models of western New England usually invoke a collision between the Laurentian margin and the Bronson Hill Arc (BHA) to account for the Taconian orogeny. However, in central Massachusetts and southern New Hampshire arc-related rocks in the BHA are 454 to $442 \mathrm{Ma}$ (Tucker and Robinson, 1990) and, therefore, younger than much of the Taconian deformation and metamorphism in western New England which began before $470 \mathrm{Ma}$. U/Pb and single-grain evaporation zircon ages combined with geochemical analyses reveal the presence of a magmatic arc, the Shelburne Falls Arc (SFA), that formed west of the BHA and the Connecticut Valley-Gaspe Synclinorium (CVGS) at 485 to 475 Ma. The SFA is extensively preserved in the Barnard Volcanics in Vermont and in the Collinsville and Hawley formations in Massachusetts. $\mathrm{La} / \mathrm{Ce}$ versus $\mathrm{Zr} / \mathrm{Hf}$ diagrams indicate distinct sources for the BHA and SFA, further suggesting that they are two separate arcs.
Zircon dating and geochemistry also provide evidence for Late Ordovician to Late Silurian volcanic and plutonic rocks that formed in a rift environment. These younger rocks are superimposed on the SFA and BHA and occupy part of the region between the arcs, including the Standing Pond Volcanics in Vermont. We interpret the SFA to have formed above an east-dipping subduction zone by Early Ordovician and suggest that collision between Laurentia and the SFA began at approximately 475 to $470 \mathrm{Ma}$ resulting in the Taconian orogeny. Thus, in our model, the Taconian orogeny was not caused by collision of the BHA with Laurentia. Instead, the BHA most likely formed above a west-dipping subduction zone that developed along the eastern edge of the newly accreted terrane near the end of the Taconian orogeny. By approximately $440 \mathrm{Ma}$ back-arc rifting began west of the BHA producing the CVGS and volcanic and plutonic rocks that span much of the Silurian.

\section{Tectonically driven fluid migration in the west Newfoundland platform: record of dolomitization, breccia, $\mathrm{Pb}-\mathrm{Zn}$ and carbonate cements}

(poster)

T. Lane

Teck Exploration Limited, Suite 7000, I First Canadian Place, Toronto, Ontario M5X IG9, Canada

Regional fluid migration through the Humber Platform was associated with episodic Paleozoic tectonism. These events profoundly altered platform stratigraphy to extensive dolostones, and veins and breccias cemented by carbonate, quartz $\pm \mathrm{Pb}$ $\mathrm{Zn}$ sulphides and sulphates. Complex alteration and cement stratigraphy records a series of deformation events associated with fluid migration.

Four discrete events are identified at Daniel's Harbour zinc mine: (1) Convergent Lithospheric Bulge: faults on a gently uplifted, early Ordovician platform focused meteoric karst, and thermal saline brines dolomitized an emergent seafloor. (2) Foreland Burial/Obduction: calcite/dolomite cements with radiogenic $\mathrm{Sr}$ precipitated in ubiquitous microfractures from allochthonous fluids. (3) Peak Thermal Convergence: regional fractures and faults released voluminous hydrothermal fluids $\left(100^{\circ}-200^{\circ} \mathrm{C}\right)$ responsible for extensive coarse stratabound dolomitization, vein cements and sulphides. (4) Late uplift: fluid migrated along steep faults to form local dolostone bodies.

Extension in the St. George's Basin (Devonian-Carboniferous) resulted in several further generations of fluid movement: (1) Initial Extension: extensive fractures and breccias in Cambro-Ordovician carbonates filled with calcitesiderite-galena-sphalerite-silica. Only minor wall rock alteration resulted. (2) "Post-Windsor" Convergence: extensive precipitation of stratabound calcite, siderite, galena, sphalerite, barite and celestite occurred within basal carbonates of the Carboniferous Ship Cove Formation above sandstone aquifers. Minerals concentrated in fault-controlled, karst breccias - along joints and faults in Ordovician platform carbonates.

\section{Northwest-vergent thrusting and tectonic wedging associated with Silurian promontory-promontory collision in the Canadian Appalachians}

\author{
S. Lin 1, C.R. van Staal ${ }^{1}$ and B. Dubé2 \\ IGeological Survey of Canada, 601 Booth Street, Ottawa, Ontario KIA OE8, Canada \\ ${ }^{2}$ Quebec Geoscience Centre, Geological Survey of Canada, 2700 Einstein Street, Ste-Foy, Quebec GIV 4C7, Canada
}

In Cape Breton Island and southwestern Newfoundland, the Central Mobile Belt is much narrower than elsewhere in the Canadian Appalachians ( $c a .50 \mathrm{~km}$ versus $>200 \mathrm{~km}$ wide). The rocks are also more strongly deformed and have been subjected to a high-grade Barrovian-type metamorphism $\left(700-750^{\circ} \mathrm{C}\right.$ at $\left.6-10 \mathrm{kbar}\right)$. The area is bounded by two transverse dextral transcurrent faults, the Canso fault to the southwest and the Gunflap Hills fault to the northeast. The geology is 
best explained by a Silurian collision between the St. Lawrence promontory on the Laurentian margin and the Cabot promontory on the Gondwanan margin. The two transcurrent faults are interpreted as tear faults that formed to accommodate differential shortening.

At the location of interpreted promontory-promontory collision, syn-collisional orogen-parallel thrusts are well developed, e.g., the Eastern Highlands shear zone in Cape Breton Island, and the Cape Ray fault zone, the Grand Bay lineament and the Bay d'Est fault zone in southwest Newfoundland. These thrusts show a consistent westward vergence. The west-vergent thrusting is in contrast with dominantly east-vergent thrusting in other parts of the Canadian Appalachians and is antithetic to the westward subduction that led to the Silurian continent-continent collision. The antithetic thrusting is interpreted by tectonic wedging at the location of promontory-promontory collision, which is supported by Lithoprobe seismic reflection data.

\title{
Faulting and progressive strain history of the Gaspé Belt during the middle Devonian Acadian orogeny: tectonic implications
}

\author{
M. Malo and D. Kirkwood \\ INRS-Géoressouces, Centre géoscientifique de Québec, Sainte-Foy, Québec GIV 4C7, Canada
}

In Gaspé Peninsula, the kinematic analysis of major Acadian faults and their relationship to the Baie Verte-Brompton Line (BBL), as well as a strain study of rocks within the Upper Ordovician to Upper Devonian Gaspé Belt are used to unravel the post-Taconian deformational history of the Acadian external zone in the Québec Reentrant. Earliest structures recorded along the BBL are pre-Silurian ductile shear zones related to Taconian accretionary processes. Late Silurian normal faults parallel to the BBL in northeastern Gaspé were active during sedimentation of the Gaspé Belt rocks. These faults are contemporaneous with the development of the Salinic disturbance and to closure of a back-arc basin further southeast (documented in New Brunswick). Middle to late Devonian brittle/ductile dextral strike-slip faulting along the BBL in northern Gaspé, and along east-trending faults (e.g., Grand Pabos) which displace the BBL in southern Gaspé, as well as northeast-trending thrust and high-angle reverse faults are related to a transpressive regime of deformation during the Acadian oblique convergence between composite Laurentia and the Gander margin of Gondwana. The transpressive strain was partitioned in time between pure shortening and reverse faulting followed by simple shear deformation with orogen-parallel extension and dextral transcurrent faulting. Reverse and strike-slip faults are probably related to a same crustal decollement at the boundary between the supracrustal sequence and the Grenville basement of composite Laurentia.

\section{Marine refraction data reveals atypical thin crust under the central Newfoundland Appalachians (poster)}

\author{
F. Marillier and I. Reid \\ Atlantic Geoscience Centre, Bedford Institute of Oceanography, P.O. Box 1006, \\ Dartmouth, Nova Scotia B2Y 4A2, Canada
}

Offshore and combined onshore-offshore seismic wideangle reflection/refraction profiles were gathered around Newfoundland as part of the 1991 Lithoprobe East seismic experiment to investigate the structure of the crust in the northern Appalachians.

Together with previous results, the new data reveal an unexpected crustal structure. West of Newfoundland, in a crustal unit correlated with the Grenville Province, the crust thins from 44 to $40 \mathrm{~km}$. In central Newfoundland, under the central mobile belt, the crust thins to $35 \mathrm{~km}$ or less. To the east, under the Avalon Zone, the crust thickens again to $40 \mathrm{~km}$.

Except for a single profile west of Newfoundland, seismic velocities in the upper crust (5.7 to $6.3 \mathrm{~km} / \mathrm{s}$ ) and in the lower crust (less than $7.0 \mathrm{~km} / \mathrm{s}$ ) are typical of continents. This indicates that no significant magmatic underplating occurred under the Newfoundland Appalachians during Mesozoic rifting of the Atlantic Ocean as proposed elsewhere for the New England Appalachians.

We suggest that crustal thinning was produced by processes such as mechanical thinning at the base of the crust during orogenic collapse, post-orogenic isostatic readjustment associated with lateral density variations within the upper mantle, or transformation by phase change of gabbroic lower crust into eclogite. 


\title{
${ }^{40} \mathrm{Ar} /{ }^{39} \mathrm{Ar}$ ages from the Lewis Hills ophilotic massif, west Newfoundland (poster)
}

\author{
A.M. McCaig and D. Rex \\ Department Earth Sciences, The University of Leeds LS2 9JT, United Kingdom
}

Three different ophiolitic assemblages occur in the Bay of Islands area of West Newfoundland: (1) the normal ophiolitic sequence of the Bay of Islands Complex (zircon age 486 Ma); (2) the Little Port Complex, dated at $505 \mathrm{Ma}$ and variously interpreted as formed in an island arc or oceanic transform environment; and (3) amphibolite gneisses and ultramafic to trondjemitic intrusives in the western Lewis Hills Massif (Mount Barren gneisses). These have in the past been correlated with the Little Port Complex and related either to transform or arc activity, but recently even this correlation has been questioned.

The western Lewis Hills assemblage is in contact to the east with an unusually thick sequence of dunitic to gabbroic cumulates thought to be part of the Bay of Islands Complex proper. The relative age of these two assemblages is of critical importance to the interpretation of ophiolite formation and emplacement in western Newfoundland. We have reexamined the contact between them and agree with Karson and Dewey (1978) that the dunites clearly intrude previ- ously deformed amphibolites. We have also performed six new $40 \mathrm{Ar} /{ }^{39} \mathrm{Ar}$ determinations on amphibole separates from the western Lewis Hills, collected at various distances from the contact with the Bay of Islands Complex dunites. An amphibolite $2.0 \mathrm{~km}$ from the contact has a plateau age of $493 \pm 5 \mathrm{Ma}$, and a pegmatite $0.5 \mathrm{~km}$ from the contact has a plateau age of $489 \pm 6 \mathrm{Ma}$. A cross-cutting microgabbro dyke which postdates the deformation has an apparent age of $500 \pm 5 \mathrm{Ma}$ but can be shown to contain excess argon using "isochron" plots. These other samples collected further from the contact have very low $\mathrm{K}$ contents and give disturbed spectra with large errors in all heatsteps. Two of these show significantly older ages, up to $1000 \mathrm{Ma}$, and most likely contain excess argon (although the presence of much older rocks cannot be ruled out).

Our data are consistent with the western Lewis Hills assemblage predating the Bay of Islands Complex, and correlation with the Little Port Complex seems likely.

\section{Contrasting isotopic signatures as constraints for the paleogeographic reconstruction of the Avalon Composite Terrane}

\author{
J.B. Murphy' ${ }^{1}$, D.R. Nance 2 , J.D. Keppie ${ }^{3}$, J. Dostal 4 and B.L. Cousens 5 \\ 1Department of Geology, St. Francis Xavier University, Antigonish, Nova Scotia B2G 1C0, Canada \\ 2 Department of Geology, Ohio University, Athens, Ohio 45701, USA \\ 3 Department of Natural Resources, P.O. Box 698, Halifax, Nova Scotia B3J 2T9, Canada \\ 4 Department of Geology, St. Mary's University, Halifax, Nova Scotia B3H 3C3, Canada \\ 5 Department of Earth Sciences, Carleton University, Ottawa, Ontario KIS 5B6, Canada
}

The importance of the Avalonian tectonostratigraphic belt in understanding ancient orogenic processes was emphasized by Hank Williams in 1964. Controversies concerning the Late Proterozoic and Early Paleozoic position of the belt and the timing and nature of its accretion to Laurentia still remain. Available $\mathrm{Nd}$ and $\mathrm{U} / \mathrm{Pb}$ (detrital zircon) isotopic data from Avalonian rocks in Nova Scotia support available paleomagnetic and biostratigraphic data that the Avalon Composite Terrane developed at the periphery of a Neoproterozoic supercontinent adjacent to the Amazonian craton. Generally positive $\varepsilon_{\mathrm{Nd}}$ values $(0$ to +6$)$ of Late Proterozoic to Early Silurian volcanic and sedimentary rocks reflect derivation from moderately depleted sources. The recurrence of $T_{D M}$ model ages between $0.95 \mathrm{Ga}$ and $1.0 \mathrm{Ga}$ is remarkable. In contrast, the $\varepsilon_{\mathrm{Nd}}$ signature of the Early Silurian sedimentary rocks in the Beechill Cove Formation are strongly negative (-4.77 to -6.08) with $\mathrm{T}_{\mathrm{DM}}$ model ages of ranging from 1.4 $\mathrm{Ga}$ to $2.7 \mathrm{Ga}$. This signature cannot be attributed to the erosion of Avalonian basement or coeval volcanic rocks. Paleocontinental reconstructions for Avalonia in the Early Silurian, although controversial in detail, suggest proximity to Laurentia, and the isotopic signatures are consistent with a Laurentian derivation thereby providing constraints on time of accretion of the Avalon Composite Terrane.

\section{The St. Mary's Basin, central mainland Nova Scotia: Late Paleozoic basin formation and deformation along the Avalon-Meguma terrane boundary \\ (poster)}

\author{
J.B. Murphy, R.J. Rice and T.R. Stokes \\ Department of Geology, St. Francis Xavier University, Antigonish, Nova Scotia B2G 1C0, Canada
}

The St. Mary's Basin, central mainland Nova Scotia, is a Late Paleozoic intra-continental fluviatile to lacustrine basinfill sequence that occupies the boundary between the Meguma and Avalon Composite terranes of the Canadian Appalachians. Paleocontinental reconstructions imply basin formation and deformation occurred during collisional orog- 
eny associated with the formation of Pangea. The sequence is assigned to the Late Devonian-Early Carboniferous Horton Group. It faces from northwest to southeast, coarsens upward and thickens towards the southeastern basin of the margin. The clasts were predominantly derived from the Meguma Terrane to the south, and it is probable that the St. Mary's Basin is underlain by Meguma basement.

A strong tectonic influence on sedimentation is apparent along the entire southern flank of the basin in which coarse conglomerates were deposited in a basin subsiding along northerly dipping listric normal faults. Dextral motion along the northern margin (Chedabucto fault) has resulted in the development of broad open northeast-trending folds that die out towards the southern margin. The character of the sediments does not vary with proximity to the Chedabucto fault suggesting that the fault does not constitute the original basin margin and that an unknown portion of the basin and its Meguma basement have been tectonically removed and may be found north of the fault.

\title{
Hank Williams - meticulous scientist wielding a broad brush
}

\author{
E.R. Neale \\ 5108 Carney Road, N.W., Calgary, Alberta T2L 1G2, Canada
}

Harold (Hank) Williams arguably has more published geological maps to his credit than any Canadian of his generation. As he maps, he ponders the significance of his findings in the context of the evolution of the Appalachian/Caledonian mountain system and then he extrapolates boldly. This led him, thirty years ago, to write on the geological symmetry of his native Newfoundland. That much-cited paper and his later (1967) map of the Island of Newfoundland were two keystones in J.T. Wilson's and others' recognition and development of the concept of an opening and closing protoAtlantic (Iapetus) ocean. Hank, in turn, became one of the first to appreciate the plate tectonic model as a key to unraveling the geometry and history of the Appalachian/ Caledonian orogen. His approach has been and remains: first, meticulous mapping of selected problem area; then, extrapolation of results to other parts of the orogen in broad brush compilations usually in co-authorship with other regional experts; finally, back to his outdoor laboratory in Newfoundland to test hypotheses and seek answers to new problems that have arisen. Little wonder that his elegant Tectonic-Lithofacies Map of the Appalachians hangs on classroom walls around the world and that his recently completed DNAG volume on the Canadian Appalachians has already excited praise from editors and reviewers. Hank Williams is indeed a worthy successor to Rodgers, Kay, King and Hall as our most knowledgeable expert on the Appalachians.

Accomplished musician; lively lecturer; inexhaustible party animal; mischievous, homespun Newfie wit and savant, Hank has generously shared his thoughts, his talents and joie de vivre with students and colleagues from all over the world through his lucid, informal, entertaining lectures and his exhilarating field trips. In the words of his friend and former professor, the late J. Tuzo Wilson: "I cannot think of any Canadian geologist more deserving of honour and recognition".

\section{Tectonic and paleogeographic significance of Late Ordovician conodonts in the Canadian Appalachians (poster)}

\author{
G.S. Nowlan 1 , A.D. McCracken2 and M.J. McLeod 3 \\ 1 Geological Survey of Canada, 3303-33rd Street, N.W., Calgary, Alberta T2L 2A7, Canada \\ 2 Geological Survey of Canada, 601 Booth Street, Ottawa, Ontario K1A 0E8, Canada \\ 3 Geological Surveys Branch, Department of Natural Resources and Energy, P.O. Box 1519, \\ Sussex, New Brunswick EOE IP0, Canada
}

Conodonts of Late Ordovician (Late Caradoc-Ashgill) age are rare in the Canadian Appalachians. They have been recovered from the Vauréal and Ellis Bay formations of the Anticosti Basin, the Matapedia and Grog Brook groups in the Matapedia Belt of Quebec and New Brunswick, from an unnamed formation in west-central New Brunswick, and from the predominantly volcanic Goss Point beds, Letang Peninsula, southwestern New Brunswick.

Faunas from the Anticosti Basin are of undoubted Midcontinent affinity. The Matapedia and Grog Brook groups, which are locally interbedded, represent basinal deposition close to the margin of Laurentia. Both units have faunas that are highly mixed both paleoecologically and provincially, containing elements of both shallow and deep water Midcontinent affinity and elements typical of the Atlantic faunal region. This implies that these basins had endemic faunas of Atlantic Province affinity with influxes of faunas from adjacent Laurentia. The limited fauna from west-central New Brunswick, also of mixed provincial affinity, is from a limestone conglomerate that rests unconformably on Middle Ordovician Craig Brook Formation of the Miramichi Anticlinorium (Gander Zone). The easternmost occurrence is within the Goss Point beds, previously believed to be part of the Mascarene Group, a Silurian cover sequence on the 
Avalon Zone. This unit has produced a meager fauna that contains species of both the Midcontinent and Atlantic faunal regions.

The fact that all faunas east of the Anticosti Basin are provincially mixed suggests that Late Ordovician conodont faunas around the Iapetus Ocean may have been more homogeneous than earlier Ordovician faunas. This may indicate that the ocean was smaller or that current patterns changed in the Late Ordovician to permit trans-Iapetan migration.

\title{
Neoproterozoic basement-cover relationships and the tectono-magmatic record of the Avalon Zone on the Hermitage peninsula and environs, Newfoundland
}

\author{
S.J. O'Brien 1 , R.D. Tucker ${ }^{2}$ and C.F. O'Driscoll ${ }^{1}$

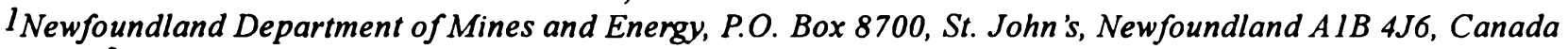 \\ 2 Department of Earth and Planetary Sciences, Washington University, St. Louis, Missouri, USA
}

Field relationships and precise $\mathrm{U} / \mathrm{Pb}$ ages reveal a protracted and episodic Neoproterozoic history for the Avalon Zone (s.s.) in southern Newfoundland and aid in demonstrating the composite nature of the Gondwanan margin of the Newfoundland Appalachians prior to the Paleozoic. On the Hermitage Peninsula, between the Hermitage Bay and East Bay faults, strata previously viewed as components of a single, conformable lithostratigraphic unit yield widely differing ages and exhibit either depositional or intrusive relationships with three Neoproterozoic plutonic suites, each of different age. Concordant $\mathrm{U} / \mathrm{Pb}$ analyses were determined for the major rock suites, implying that crustal contamination, as indicated by the presence of inherited zircon, was successfully avoided during sample selection. The oldest dated pluton, a $673 \pm 3$ Ma granite of the Furby's Cove Intrusive Suite (FCIS), has intruded the $682 \pm 3 \mathrm{Ma}$, arc-like Tickle Point Formation (TPF). The $626 \pm 3 \mathrm{Ma}$, volcano-sedimentary Connaigre Bay Group (CBG) rests with profound unconformity upon the FCIS, unaffected by ductile shear zones in the subCBG basement. The $621 \pm 3 \mathrm{Ma}$, calc-alkaline Simmons Brook Intrusive Suite (SBIS) intrudes the CBG as well as mafic gneisses and mylonites - the latter posttectonically. The SBIS was deformed with its country rocks prior to emplacement of the $567 \pm 3 \mathrm{Ma}$ Grole Intrusive Suite (GIS) across the sub-CBG unconformity. Elsewhere on the peninsula, $567 \pm 3$ Ma diorites were locally emplaced into syn-magmatic shear zones and in some cases caused migmatization of adjacent country rocks. A nearcomplete Late Neoproterozoic stratigraphic record occurs in the Long Harbour Group (LHG), the base and top of which are dated at $568 \pm 5 \mathrm{Ma}$ and $552 \pm 3 \mathrm{Ma}$, respectively. The younger LHG age represents the maximum age for the Proterozoic-Paleozoic boundary, the global stratotype for which is designated in the overlying Chapel Island Formation. The LHG, which may be cover to the $c a$. $620 \mathrm{Ma}$ and older rocks west of the East Bay Fault, is time- and in part, litho-stratigraphic equivalent of much of the classic Ediacaran-bearing and younger Neoproterozoic succession of the Avalon Peninsula. $\varepsilon_{\mathrm{Hf}}$ values of the zircon aliquots used for age determination range from -5.5 to 10.2 , implying that all suites formed from magmas that were variously enriched with evolved $176 \mathrm{Hf} / 177 \mathrm{Hf}$. For most suites, the source of the evolved Hf may be modeled as slightly older sialic crust, but for the case of the SBIS, a middle Proterozoic crustal contaminant is clearly indicated.

\section{Dunnage-Gander boundaries, and some aspects of terrane evolution in Newfoundland}

\author{
M.A.J. Piasecki \\ Department of Geology, Keele University, Keele, Staffordshire ST5 5BG, United Kingdom
}

Dunnage-Gander boundaries along the GRUB line, Bay d'Espoir and around the Meelpaeg inliers are marked by kilometers-wide, Silurian ductile shear zones dominated by orogen-parallel sense of shear transport. They share a common sequence of Silurian shearing movements, which obliterated most fabrics of initial Ordovician interaction.

The main phase of transport, $D_{1}$, was directed northover-south in flat rocks, becoming sinistral transcurrent in their upturned eastern limbs, and dextral in upturned western limbs. Related accommodation movements, $D_{2}$, were northwest-directed thrusts, notably the Noel Paul's-Cape Ray Fault zone. Renewed orogen-parallel shearing, $D_{3}$, reactivated $\mathrm{D}_{1}$ shear zones, but with an opposite sense of movement. $D_{3}$ shearing overprinted $D_{1}$ polarity in shear zones now engulfed in the Burgeo batholith and displaced the $D_{2}$ Noel Paul's-Cape Ray Fault zone along the $D_{1}-D_{3}$ Gunflap Hills fault zone.

Adjacent to the Dover-Hermitage fault zone and along the Hermitage flexure, Gander and Dunnage mylonites steepen, prograde to migmatites and pass into syn-shearing Silurian granites; and the polarity of Silurian shear transport swings in parallelism with the bent axes of the orogen. It is proposed that, along this plutonic belt, partial melting of actively shearing crust led to more rapid sinistral $D_{1}$ transport than in the flat belt of cooler rocks moving north-oversouth, thus generating the Hermitage flexure, to maintain the internal cohesion of the Dunnage-Gander slab. 


\title{
Lower palaeozoic circum-Atlantic history from the Late Precambrian to the Middle Devonian
}

\author{
K.T. Pickering1 and A.G. Smith2 \\ 1 Department of Geological Sciences, University College London, Gower Street, London WCIE 6BT, United Kingdom \\ 2 Department of Earth Sciences, University of Cambridge, Downing Street, Cambridge CB2 3EQ, United Kingdom
}

The ca. 620 to $570 \mathrm{Ma}$ breakup of Gondwana led to the creation of a Mesozoic Tethys-like or Mediterranean-type ocean basin, the Western Iapetus Ocean between Laurentia and South America. At that time, the ca. 650 to $500 \mathrm{Ma}$ subduction-related Cadomian and associated tectonothermal events occurred along an active, mainly Andean-type, convergent continental margin facing a much older and very wide Pacific-type ocean basin, here named the Eastern Iapetus Ocean. The main Lower Palaeozoic tectonothermal events were as follows: (1) 620 to $570 \mathrm{Ma}$ breakup of Gondwana, with the Andean margin of South America rifting from the eastern margin of Laurentia to create the Western Iapetus Ocean. The Eastern Iapetus Ocean was already in existence, and Gondwana was associated with a landward-dipping subduction zone (Cadomian, Grampian, Penobscotian, Famantinian, and possibly some "Finnmarkian" events); (2) 490 to $470 \mathrm{Ma}$ marginal basin development, followed by ophiolite obduction along northern/northwest margin of Laurentia (early or precursor stage of arc-continent collision between Laurentia and an outboard arc system [M'Clintock, Early Caledonian, Taconic]). During this time, there is no convincing evidence for continent-continent collision between Laurentia and South America; (3) 480 to 470 Ma second phase breakup of Gondwana, with Baltica, Eastern and Western
Avalonia, the Carolina slate belt, Piedmont, and other North American exotic continental blocks rifting from Gondwana; (4) 460 to $430 \mathrm{Ma}$, peak ca. $450 \mathrm{Ma}$, orogenic events involving continuing arc-continent collision/s; (5) 435 to 400 Ma destruction of remaining parts of the Iapetus Ocean (Scandian 430 to $400 \mathrm{Ma}$; Acadian Siluro-Devonian = Late Caledonian/Acadian, to $380 \mathrm{Ma}$; and Ligerian 390 to 370 Ma collision of Gondwana-derived Aquitaine-Cantabrian blocks with Eastern Avalonia-Baltica). Like the Pacific Ocean today, the Eastern Iapetus Ocean was many thousands of $\mathrm{km}$ wide, had a long and complex history of island arc development spanning at least $\mathbf{4 0 0}$ million years, and was associated with a phase of marginal basin formation which was of short duration ( $<30$ million years), particularly on its Laurentian margin side, together with major strike-slip tectonics, and therefore was similar to the Pacific Ocean basin. Also, like the Pacific, it was an essentially north-south elongated ocean. In contrast, the Western Iapetus Ocean appears to have been much narrower, shorter lived (probably $<100$ million years), and associated with the rifting to form two opposing passive carbonate margins, analogous to the Mesozoic Tethys or the present-day Mediterranean. Also, like its Tethyan or Mediterranean counterparts, the Western Iapetus was an eastwest oriented ocean basin.

\section{Lower Paleozoic foredeep basin fill in western Newfoundland}

\author{
L. Quinn \\ Department of Geology, Brandon University, Brandon, Manitoba R7A 6A9, Canada
}

Early sedimentation in the western Newfoundland foredeep basin is represented by the Goose Tickle Group (GTG-Llanvirn?Llandeilo), and the Lower Head Formation (LHF-ArenigLlanvirn).

The GTG is dominated by sand poor turbidites which were deposited under anoxic conditions in the narrow, oversupplied foredeep. Debris flows were shed in front of faults generated during emplacement of Taconic Allochthons. Sediment was supplied at three different input points whose positions closely reflect those of independently inferred structural discontinuities.

The allochthonous LHF records the evolution of a confining satellite basin(s) fed by sandy fans and bounded by steep subaerially exposed scarps. Syndepositional tectonic activity in both the GTG and LHF is indicative of foredeep splitting.
The GTG and LHF are petrographically similar and much of the detritus is related to lithologies in the Taconic Allochthons. Extrabasinal grains including felsic volcanics and 2 b.y. old microclines suggest, however, that the allochthons are remnants of a much more complex uplift which included passive margin sediments, possibly Grenville and older basement, and a major arc terrane under compression. Detritus was mixed in a now destroyed basin(s) prior to final supply to the foredeep.

Two separate sequences of shallow marine to terrestrial siliciclastics were deposited during the Caradoc and Pridoli. They record the appearance of a metamorphic source with a prominent petrographic signature and represent Acadian evolution of the source area. 


\title{
Late Neoproterozoic Precambrian development of Gondwana
}

\author{
N. Rast 1 and J.W. Skehan 2 \\ IDepartment of Geological Sciences, University of Kentucky, Lexington, Kentucky 40506-0059, USA \\ 2 Weston Observatory, Department of Geology and Geophysics, Boston College, Weston, Massachusetts 02193, USA
}

Gondwana has been defined by Du Toit (1937) and since then has been divided into East and West Gondwana. These divisions refer to the two parts which comprised a portion of Pangaea in Triassic times, along a line separating Africa from South America and North America. Hoffman (1991) considered it as part of Middle-Late Proterozoic Rodinia. The breakup of Rodinia in this hypothesis occurred in Late Proterozoic times. In the proposed assembly of Gondwana, the Laurentian craton of North America and Greenland, Baltica, Amazonia, West Africa, Congo and Sao Francisco, Kalahari and several others took place with the Laurentian craton being central to this assembly. The reason for abandoning the previously existing scheme of the Iapetus Ocean separating North and South America from Africa and Pangaea was due to finding a strip of rocks with lithologic and partly tectonic characteristics similar to the Avalon Terrane. Also, it was desirable to place parts of Antarctica and Australia next to the western Laurentian craton. Thus, the general similarity of the Avalon of North America to the Late Proterozoic of West Africa was discounted prematurely across the trend in favor of correlation with similar rocks of Central South America. We propose that as yet, it has not been demonstrated, and that the trace of the Avalon Terrane can be followed from North America through parts of South America where it separates the Amazon craton from the Sao Francisco and continues to the West of La Plata. As a result, a different Iapetus Ocean can be recreated.

\section{Tectonostratigraphy, event horizons, subduction cycles and plate rotations in the development of the Scandinavian Caledonides}

\author{
D. Roberts and B.A. Sturt \\ Geological Survey of Norway, Post Box 3006-Lade, 7002 Trondheim, Norway
}

The tectonostratigraphic mosaic which constitutes the Scandinavian Caledonides embraces shelf and miogeoclinal sequences indigenous to Baltica, and imbricated, outboard, suspect and exotic terranes comprising fragmented ophiolitic and arc complexes and their sedimentary accoutrements. Separation into disparate terranes, each with discrete tectonometamorphic histories, is being continually refined by geochronology and revealing the complexity of orogenic evolution. Following a "westward" subduction, locally to eclogite-generating depths, in earliest Ordovician time, ophiolite obduction and early nappe development occurred during the Tremadoc/Arenig, possibly with temporal and geographic separation along palaeotransforms. Uplift and erosion of the ophiolites and early thrust-sheets preceded a second major magmatosedimentary cycle characterized by terrane-linking unconformities and important event horizons. Developing marginal basins with, in places, second-stage ophiolite generation, as well as significant arc and batholithic constructions in some regions, also characterize this Mid Ordovician to Early Silurian period. Taconian-equivalent deformation is registered in some terranes prior to batholith emplacements. It has been suggested that Ordovician deformation, including the early subduction/obduction cycle, may relate to Baltica-Siberia plate movements rather than to a Laurentian connection.

The events leading up to the Mid Silurian/Early Devonian, Scandian, Baltica-Laurentia subduction and collision are quite neatly explained in the context of palaeomagnetic data that favour an anticlockwise-rotating Baltica which gradually drifted northwards towards lower latitudes through Ordovician-Silurian time. Exotic terranes caught between the southward-drifting Laurentia and rotating Baltica were sinistrally sheared (strike-slip) just before participating in the violent Scandian collision which first affected what is today southern Norway. The collision and subduction are recorded in eclogite generation and ultra high-pressure metamorphism in western areas. Northwards, the diachronous collision was somewhat less violent, and eastward thrusting occurred there simultaneously with orogenic collapse and Devonian extensional/transtensional basin sedimentation in the south.

\section{The Carolina Terrane: is it part of Avalon?}

\author{
S.D. Samson \\ Department of Earth Sciences, Syracuse University, Syracuse, New York 13244-1070, USA
}

The Carolina Terrane of the southern Appalachians is one of the largest terranes in the entire orogen. Because it contains a number of lithologic, chronologic and faunal similarities to the Avalon Terrane, it is often considered to be the southernmost portion of Avalon. However, gross simi- larities may exist between crustal blocks that have had significantly different evolutionary histories. A full understanding of the chemical evolution of a terrane is thus fundamental to determining its affinity to any other crustal fragment.

$\mathrm{Nd}$ data have recently become available for the Avalon 
Terrane in Canada. Most samples from Newfoundland have moderately high positive initial $\varepsilon_{\mathrm{Nd}}$ values indicating that this part of Avalon is composed of juvenile crust. The $\varepsilon \mathrm{Nd}$ values for New Brunswick and Cape Breton Island are in general lower, most are between -1.5 to +2.5 , indicating a greater degree of a more evolved crustal component. The oldest igneous rocks within the Carolina Terrane have $\varepsilon \mathrm{Nd}$ values ranging from +1.5 to +5.9 , although most values are $>+3.5$; thus, the terrane is similar to Avalon, although possibly less isotopically evolved.

$\mathrm{U} / \mathrm{Pb}$ zircon geochronological studies also provide insight into the nature of terranes. $\mathrm{U} / \mathrm{Pb}$ studies of Cape Breton Island and Newfoundland show no evidence of inherited zircons. New U/Pb zircon data from St. John, New Brunswick, how- ever, do show evidence of ancient xenocrysts. Rare, round pink zircons from a tuff at the Precambrian-Cambrian boundary have a ${ }^{207} \mathrm{~Pb} / 206 \mathrm{~Pb}$ age of $2660 \mathrm{Ma}$. This age is comparable to the ages of pink detrital zircons extracted from an overlying volcaniclastic rock. Average ${ }^{207} \mathrm{~Pb} / 206 \mathrm{~Pb}$ ages of multigrain zircon fractions range from 2214 to $2360 \mathrm{Ma}$ while two single zircon have ages of 2472 and $2612 \mathrm{Ma}$. The xenocrystic age of zircons from the volcanic is direct evidence that this part of Avalon was constructed on Archean crust; the detrital ages indicate that ancient crust was exposed as a source of the sediment. Similar evidence of zircons with such antiquity has yet to be documented for the Carolina Terrane. Either Carolina is not part of Avalon, or its ancient ancestry has yet to be discovered.

\title{
Late Proterozoic tectonic events in the Avalon Terrane including the Cadomian and Pan-African
}

(poster)

\author{
J.W. Skehan 1 and N. Rast ${ }^{2}$ \\ 1 Weston Observatory, Department of Geology and Geophysics, Boston College, Weston, Massachusetts 02193, USA \\ 2 Department of Geological Sciences, University of Kentucky, Lexington, Kentucky 40506-0059, USA
}

The Avalon Terrane has been defined in the Northern Appalachians (NAP) (Williams, 1964; Williams and Hatcher, 1983) and by extension has been continued into the southern Appalachians. There, because of Alleghanian overprint and locally poor quality of exposure, its details are still controversial. In NAP, the earliest tectonic event recognized is rifting in the Burin Peninsula at $763 \mathrm{Ma}$. The next is the Avalonian orogeny $c a$. $620 \mathrm{Ma}$ with mild metamorphism and granite intrusion. Between the two there has been an undated, but important deformation phase (Krogh et al., 1988, p. 453). This undated episode is important in correlation and may be equivalent to Pan African I.

Pan African II is possibly represented by the Avalonian orogeny, and there is a series of local, Late Proterozoic minor episodes. All these events can be matched with the Boston Avalon where the earliest events produced the Burlington shear zone, while later events, also of Precambrian age, resulted in the Nobscot shear zone and possibly the deformation of the Boston Bay Group on parallel east-west trends. We propose the term Pan-African III for these episodes. In Newfoundland and Nova Scotia there is also evidence of a Middle- to Late-Cambrian episode of volcanicity and deformation, implying a date of $c a$. 500 to $520 \mathrm{Ma}$. Similar events are described from Central and Western Britain, Armorica, Spain, East Africa, the Arabian Peninsula and adjacent areas.

\section{Palinspastic analysis of the Taconian and Acadian hinterland in central Vermont (poster)}

\author{
R.S. Stanley, D.C. Martin and M.J. Warren \\ Department of Geology, Perkins Hall, University of Vermont, Burlington, Vermont 05405, USA \\ and \\ Queens University, Kingston, Ontario K7L 2N6, Canada
}

The $50 \mathrm{~km}$ cross section from the Middle Ordovician foreland shales in western Vermont to the Silurian-Devonian Waits River Formation in eastern Vermont is a product of Taconian and Acadian deformation. The western half consists of multiple generations of imbricated thrust sheets of pre, syn, and post metamorphic character. These rocks consist of Late Proterozoic through Cambrian rift-drift clastics and their associated North American Middle Proterozoic crust which were carried westward on the Champlain thrust zone over the Cambrian-Ordovician carbonate-siliciclastic platform and overlying foreland shales. Structural complexity and metamorphic ${ }^{39} \mathrm{Ar} / 40 \mathrm{Ar}$ ages $(470 \mathrm{~m}$.y.) indicate deformation during the Taconian orogeny in a plate configuration similar to Taiwan.
To the east bedded metasandstones, metasiltstones and phyllites of the Mississquoi Group (Middle Ordovician) overlie the more highly deformed heel of the Taconian accretionary wedge. The Mississquoi Group is interpreted as contourites deposited in the syn- to post-Taconian fore-arc basin. The Silurian-Devonian turbiditic rocks to the east are deposited on these rocks along a disconformity marked by discontinuous conglomerates.

The Acadian fabric in the Silurian-Devonian sequence can be traced westward across the Mississquoi Group (forearc basin) into the heel of Taconian accretionary wedge. The Roxbury Mylonite Zone represents the Acadian basal decollement along which the Mississquoi Group, and the Silurian-Devonian sequence was transported westward over 
the Taconian accretionary wedge. Subsequent flattening and west-over-east rotation reflect late incipient back folding of the composite cross section for central Vermont. Palinspastic analysis suggests that the present cross section is approximately 25 percent of its original width.

\title{
Palaeobiogeography and faunal dynamics in the lower to middle Ordovician of western Newfoundland of the lapetus Ocean region
}

\author{
S. Stougel and W.D. Boyce 2 \\ 1 Geological Survey of Denmark, Thoravej 8, 2400 Copenhagen NV, Denmark \\ 2Newfoundland Mapping Section, Geological Survey Branch, Department of Mines and Energy, P.O. Box 8700, \\ St. John's, Newfoundland AlB 4J6, Canada
}

Differentiation of Ordovician faunal groups into provinces in the North Atlantic Region is not strictly comparable with palaeogeographical models and does not relate clearly to criteria for recognizing continental margins and separation across the Iapetus Ocean.

Recently published and unpublished stratigraphic and palaeoecological evidence from Laurentia is reviewed. The approach of faunal dynamics, that is, changes of faunas in time and space is used. The cyclic interchange between faunal associations between platform and slope environments is evaluated during early and middle Ordovician time. The study is based on trilobites and conodonts from western Newfoundland and compared with evidence from Scotland, Norway, Greenland and Spitsbergen.

The distribution of faunal associations along the edge of the craton suggests a pattern of concentric perhaps depthrelated facies belts. Cyclic appearance of deeper water marginal faunas onto the platform characterized Tremadoc and early Arenig time, but interrupted by an extinction event at the Tremadoc/Arenig Series boundary. The lower Boat Harbour faunal associations were replaced by the upper Boat Harbour/ Catoche faunal associations. Platform uplift in middle to late Arenig forced faunas to migrate to other areas such as Greenland and Spitsbergen. Foundering of the platform in late Arenig and early Llanvirn allowed the Table Head fauna not only to migrate across the platform, but also the Iapetus Ocean, and the taxa appeared in Baltica. However, some taxa associations that were earlier adapted to cool, normal marine waters were able to cross the Iapetus Ocean at the time of its presumed maximum extent.

The palaebiographical migration-immigration pattern is governed by relative sea level changes and tectonics. The model gives an understanding of the faunal dynamics within the North Atlantic Region and helps to constrain the definition of continental margins using faunal evidence.

\section{Geochemical and isotopic signatures of Cambro-Ordovician volcanism and plutonism in the Notre Dame Subzone, Newfoundland Appalachians; magmatic evolution of the Laurentian margin of lapetus}

\author{
H.S. Swinden 1 , G.A. Jenner ${ }^{2}$ and A.Z. Szybinski2 \\ INewfoundland Geological Survey Branch, P.O. Box 8700, St. John's, Newfoundland A1B 4J6, Canada \\ 2 Department of Earth Sciences, Memorial University of Newfoundland, St. John's, Newfoundland AIB 3X5, Canada
}

Early Paleozoic volcanics in the Notre Dame Subzone (NDS) are widely interpreted to have formed in intra-oceanic arcs and back-arc basins and been accreted to the Laurentian margin during the middle Ordovician Taconic Orogeny. However, new geochronologic and $\mathrm{Nd}$ isotopic data from western Notre Dame Bay show that the Cambrian intra-oceanic Lushs Bight Group is cut by $\sim 490 \mathrm{Ma}$ high-Mg dykes that have $\varepsilon_{\mathrm{Nd}}$ of +2 to -3 , indicating a substantial involvement of continental lithosphere in their petrogenesis. Therefore, the oldest arc sequences in the NDS may have been emplaced upon continental lithosphere prior to $\sim 500 \mathrm{Ma}$.

Geochemical and Nd isotopic signatures in Early Ordovician ( $c a .488-478 \mathrm{Ma}$ ) ophiolitic rocks indicate derivation from depleted mantle sources $(\varepsilon \mathrm{Nd}>+6)$. However, the youngest NDS calc-alkalic arc rocks of the Buchans-
Robert's Arm volcanic belt ( $c a .474 \mathrm{Ma}$ ) have $\varepsilon_{\mathrm{Nd}}=+5$ to -3 . Both geochemical and isotopic data for these rocks suggest a role for continental lithosphere in their petrogenesis.

Involvement of continental lithosphere in the petrogenesis of Early Paleozoic rocks in the NDS is not accounted for in current tectonic models. Credible tectonic models must consider: (i) late Cambrian emplacement of island arc sequences over continental crust, (ii) early Ordovician ophiolite generation largely from uncontaminated mantle, and (iii) close spatial and temporal juxtaposition depleted oceanic mantle derived rocks and continentally-contaminated calc-alkalic rocks. Revision of our current tectonic models and potentially a radical re-thinking of the evolution of the Laurentian margin, is required. 


\title{
Evolution of recesses and salients of an orogenic belt from promontories and embayments of a rifted continental margin
}

\author{
W.A. Thomas and B.M. Whiting \\ Department of Geological Sciences, University of Kentucky, Lexington, Kentucky 40506-0053, USA
}

The shapes of recesses (cratonward-concave angular bends) and salients (cratonward-convex broad curves) of an orogenic belt are generally interpreted to be genetically related to promontories and embayments, respectively, of a pre-existing rifted continental margin. During rifting, promontories and embayments are framed orthogonally by rift segments and transform faults. Three-dimensional mechanical and thermal models predict distinctive structural styles and syn-rift accumulations along various rift and transform segments of a continental margin. Similarly, post-rift (passive-margin) subsidence history varies predictably along a rifted margin. During tectonic convergence and thrusting onto a passive margin, the shape of an orogenic belt adapts to the shape of the pre-existing continental margin, and part of that adaptation is reflected in the distribution of foreland-basin subsidence in response to emplacement of thrust loads. Specifics of foreland subsidence depend on several variables, in- cluding age of the post-rift, pre-orogenic lithosphere; crustal faults inherited from rifting; and composition and geometry of the thrust belt.

As an example of the genetic relation of recesses and promontories, the Alabama recess of the late Paleozoic Appalachian-Ouachita orogenic belt mimics the shape of the Alabama promontory, which was framed during the late Precambrian-Cambrian rifting by rift segments on the southeast and a transform fault on the southwest. Quantitative comparisons of crustal subsidence during late syn-rift, passive-margin, and orogenic phases around the Alabama promontory and Alabama recess document variations that are consistent with predicted differences between rift and transform segments of a rifted margin and with diachronous emplacement of separate thrust loads onto the margins of the promontory.

\section{Appalachian terranes and structure of the central mobile belt: a paleomagnetic perspective of Newfoundland's geology}

\author{
B.A. van der Pluijm and R. van der Voo \\ Department of Geological Sciences, University of Michigan, Ann Arbor, Michigan 48109-1063, USA
}

Paleomagnetic data of volcanic units in the Central Mobile Belt (CMB) of the northern Appalachians provide quantitative information on the Ordovician paleogeography of the Iapetus Ocean and Silurian closure of this sea, and limit permissible geotectonic models of the Appalachian-Caledonian orogen. The Iapetus Ocean was bordered by the Laurentian margin to the north (at $10-20^{\circ} \mathrm{S}$ paleolatitude) and the Avalonian margin to the south (at $>50^{\circ} \mathrm{S}$ ) in the Early Ordovician; the African margin of Gondwana was located yet farther south. The Moreton's Harbour Group (MH) represents an arc that formed near the Laurentian margin $\left(c a .11^{\circ} \mathrm{S}\right)$, probably separated from the craton by a small back-arc basin. The Robert's Arm, Chanceport and Summerford groups (RACS) of north central Newfoundland were part of a chain of ocean islands (arc) toward the middle of the basin $\left(30-33^{\circ} \mathrm{S}\right)$. The Lawrence Head (LH) volcanics are now located directly to the southeast of the RACS belt, but preliminary work shows a paleolatitude of $c a$. $11^{\circ} \mathrm{S}$ (similar to the MH arc). Moreover, preliminary data on the Buchan's Group also indicate a low paleolatitude, thus, it may have been part of a nearLaurentian MH-LH-B belt. CMB terranes near the southern margin of Iapetus to date are only represented by the Tetagouche Group of northern New Brunswick at $53^{\circ} \mathrm{S}$. The paleogeography of the arc belts indicates the presence of subduction zones at both margins of Iapetus as well as within. However, the Ordovician-Silurian latitudinal histories of Laurentia and Avalon require that northerly subduction under Laurentia was a prominent system, which ultimately was responsible for the closure of Iapetus. This subduction system is also indicated by accretionary wedge polarity and recent geophysical modeling (Gurnis, 1992). The style of (Ordoviciant) Silurian accretion was transpressional, based on the relative motions of Laurentia and Avalon/Gondwana, as well as the complex interfingering of the RACS and MH-LH-G belts in the CMB and other geologic evidence. These results complicate the localization of major boundaries ("sutures") in the CMB and the proposed Notre Dame-Exploit subdivision, but allow for an internally consistent tectonic model.

\section{Arenig and younger evolution of the Gander margin: a comparison of the New Brunswick and Newfoundland segments}

\author{
C. van Staal 1, G. Dunning 2 , P. Valverde 2 , J. Burgess ${ }^{3}$ and M. Brown 3 \\ IGeological Survey of Canada, 601 Booth Street, Ottawa, Ontario KIA OE8, Canada \\ 2 Memorial University of Newfoundland, St. John's, Newfoundland A1B 3X5, Canada \\ 3 University of Maryland at College Park, Maryland 20742, USA
}

The tectonic evolution of the Gander margin of the northern Appalachians likely will only be understood by combining critical data from different segments. In the New Brunswick segment a marginal basin formed by splitting an Arenig arc 
that was partly developed on the Gander margin during the late Arenig to Llanvirn ( $=470 \mathrm{Ma})$. The time of closure of this back-arc basin and initial collision between Avalon and Laurentia are well constrained as blueschist formed in Gander cover rocks on the Ashgill (447 Ma). Collision continued until the Late Silurian $(\approx 415 \mathrm{Ma})$.

Remnants of a coeval arc-backarc system are also well preserved in the Exploits Subzone in Newfoundland, but a link with the Gander margin is only clear in southwest Newfoundland. Here, a dense tholeiitic dike swarm and associated intrusives ( $\mathrm{U} / \mathrm{Pb}$ zircon: $470 \mathrm{Ma}$ ) in the Gander margin rocks and spatially related basalts in its cover represent evidence for an Early to Middle Ordovician rifting event. Deformation in southwest Newfoundland is constrained by the Port aux Basques granite (U/Pb zircon: $453 \pm 3 \mathrm{Ma}$ ), which cuts $S_{1}$, but locally contains a $S_{1}$ foliation that is folded by $F_{2}$. Hence, we interpret the granite as a late syn$D_{1}$ intrusion. $D_{1}$ and $D_{2}$ in southwest Newfoundland form part of a continuous deformation characterized by recumbent folding and late-syn $\mathrm{D}_{2}$ thrusting. Growth of kyanite probably started late during $\mathrm{D}_{1}$ and continued to grow during $\mathrm{D}_{2} . \mathrm{D}_{2}$ coincided with peak temperature conditions ( $c a$. $700^{\circ} \mathrm{C}$ ), which have been dated by monazites and syn- $\mathrm{D}_{2}$ granites at 420 to $414 \mathrm{Ma}$. Metamorphic pressure during $D_{2}$ reached 7 to $9 \mathrm{~kb}$, which required a minimum of $25 \mathrm{~km}$ of tectonic overburden during a clockwise P-T-t path. Although the tectonic setting and style of deformation in the New Brunswick and Newfoundland segments are similar, the much higher P-T conditions in southwest Newfoundland are interpreted to reflect the collision between two promontories.

\title{
How far were the Newfoundland Taconian allochthons transported during the Salinic and Acadian orogenies?
}

\author{
J.W.F. Waldron 1 and G.S. Stockmal2 \\ 1Department of Geology, Saint Mary's University, Halifax, Nova Scotia B3H 3C3, Canada \\ 2 Geological Survey of Canada, Institute of Sedimentary and Petroleum Geology, 3303-33rd Street, N.W., \\ Calgary, Alberta T2L 2A7, Canada
}

Seismic reflection data, from both the LITHOPROBE East deep seismic program and from industry sources, indicate that the platform succession of western Newfoundland was transported tens of kilometers or more during the SiluroDevonian Salinic and Acadian orogenies. Structural and stratigraphic relationships on land support this interpretation of Humber zone tectonics. The absolute position of the Taconian allochthons in western Newfoundland at the end of the Taconian orogeny can be estimated, based on calculations of flexure of an elastic lithospheric plate in response to tectonic loading.

Industry seismic and potential field data indicate the presence of thick foreland basin sediments beneath the Gulf of St. Lawrence; correlation with on-land outcrops allows subdivision into Middle Ordovician (Taconian) and Upper Ordovician and younger (Salinic and Acadian) packages. Importantly, the thickness of Taconian foreland sediments is less than $10 \%$ of the preserved thickness of Salinic and Acadian foreland sediment in the immediate offshore. The Taconian sediments thin to zero a few tens of kilometers to the west. This relationship implies that the Taconian tectonic loads were much smaller than Salinic-Acadian loads, or more distant, or both.

We assume a relatively simple, flexural foreland basin, and an effective length for the flexural plate during Taconian orogenesis that was not shorter than at the present day. For reasonable values of density, plate strength, and pre-existing passive margin geometry, our calculations indicate that the toe of the Taconian allochthon was $-75 \mathrm{~km}$ from the present-day deformation front, implying at least that much transport since the Middle Ordovician. The position of the passive margin hinge line (shelf-slope) break prior to overthrust emplacement and structural incorporation into the SalinicAcadian Port au Port Allochthon was $\sim 115 \mathrm{~km}$ from the present-day deformation front $(\sim 10 \mathrm{~km}$ west of the Red Indian Line).

These arguments imply that the magnitude of Acadian overthrusting was far greater than previously interpreted and suggest that substantial amounts of Laurentian crust must be present at depth beneath central Newfoundland.

\section{Alleghanian dextral transtension along a portion of the Carolina slate belt- Milton belt boundary, North Carolina \\ (poster)}

\author{
J.K. Wilkins, J.P. Hibbard and G.S. Shell, Jr. \\ Department of Marine, Earth and Atmospheric Sciences, Box 8208, North Carolina State University, \\ Raleigh, North Carolina 27695, USA
}
Alleghanian shortening in the southern Appalachian foreland has been recognized for many decades, but recently, many workers have documented the local, if not regional, importance of extensional tectonics in the hinterland dur- ing this event. Recent field studies along the boundary be-
tween two first-order elements of the southern Appalachian orogen, the Carolina slate belt (CSB) and the Milton belt (MB), has revealed that extension in conjunction with dex- tral shear has played a crucial role in the interaction be- tween these belts. 
It appears that motion along this boundary, the Hyco shear zone (HSZ), was partitioned into some regions where dextral motion was predominant and others where extensional motion was primarily active. Dextral shear sense can be recognized in these rocks by S-C fabrics, shear bands, winged porphyroclasts and asymmetric folds. The extensional component of deformation can be recognized by S-C fabrics, and tight to isoclinal recumbent folds with a CSB down to the south asymmetry.

This portion of the HSZ is oriented at approximately
$\mathrm{N} 70^{\circ} \mathrm{E}$, whereas other shear zones related to the Eastern Piedmont fault system are generally oriented at $\mathrm{N} 30^{\circ} \mathrm{E}$. It is likely that this portion of the HSZ represents an extensional jog along this fault system. An extensional component to the relative motion between the CSB and MB provides a plausible explanation for the present juxtaposition of high grade MB gneisses against low grade metaigneous rocks of the CSB. A lower age constraint for this motion is provided by the pre- to syn-kinematic Yanceyville metagranite that is dated at $340 \mathrm{Ma}$.

\title{
Faunal provincialism and paleogeography of lapetus - an update for the $90 \mathrm{~s}$
}

\author{
H.S. Williams 1 , D.A.T. Harper ${ }^{2}$, R.B. Neuman ${ }^{3}$, W.D. Boyce 4 and C.M. Niocaill ${ }^{3}$ \\ IDepartment of Earth Sciences, Memorial University of Newfoundland, St. John's, Newfoundland A1B 3X5, Canada \\ 2 Department of Geology, University College, Galway, Ireland \\ 3 MRC 137 Natural History Museum, Smithsonian Institution, Washington, DC 20560, USA \\ ${ }^{4}$ Newfoundland Department of Mines and Energy, Geological Survey Branch, P.O. Box 8700, \\ St. John's, Newfoundland AlB IJ6, Canada
}

The recognition of contrasting faunal assemblages in the Lower Paleozoic of eastern and western Newfoundland was critical in confirming J. Tuzo Wilson's classic hypothesis regarding the presence of a proto-Atlantic, now Iapetus, Ocean which once separated Europe from North America. Despite the use of many other techniques in paleogeographic studies, such as paleomagnetism, detailed geochemistry, deep crustal geophysics and structural geology, paleontology remains the key component for both suggesting and testing hypotheses generated by these other approaches. Moreover, description of statistical analysis of many new faunas from the Appalachian-Caledonian mountain belt, particularly Newfoundland, have emphasized a greater latitudinal variation in biogeography, recognizing not only platform provinces, but also marginal and island faunas that developed within the Iapetus Ocean. Studies of sedimentology and regional geology show that rocks which contain the Celtic province faunas belonged to a middle- to high-latitude, cool water realm that was separated by $c a .20^{\circ}$ of latitude from the low-latitude, warm water realm of the Toquima-Table Head province during the early Ordovician (Arenig-Llanvirn), and that by mid-Ordovician the distinction between the two biogeographic units was less marked.

Recent integrated studies have permitted a far more critical understanding of the dynamic plate tectonic history of Iapetus during the Cambrian, Ordovician and Silurian, including the recognition of several probable sutures, correlation of tectonostratigraphic terranes throughout the AppalachianCaledonide orogen and changing faunal affinities through time within, for example, the Exploits Subzone (Newfoundland) and equivalent Grangegeeth Terrane (Ireland) and Southern Uplands (Scotland). New faunal data and analytical techniques increasingly depict a complex oceanic system punctuated by mobile island terranes with changing faunal signatures.

\section{Review of volcanic and sedimentary terrane correlation between the Canadian Appalachians and British Caledonides}

\author{
J. Winchester ${ }^{1}$ and C. van Staal 2 \\ 1Department of Geology, Keele University, Staffs ST5 5BG, England \\ 2 Geological Survey of Canada, 601 Booth Street, Ottawa, Ontario KIA OE8, Canada
}

Correlation of metavolcanic and associated sedimentary assemblages from Newfoundland into New Brunswick and Maine based on lithology, tectonic setting, faunal provinciality and paleomagnetic data has led to a reappraisal of the tectonic evolution of the Appalachian orogen. Both the Laurentian and Avalonian margins experienced an Early to Middle Ordovician arc-continent collision when faunal separation between them was greatest. Following accretion of these two arcs (Notre Dame and Gander arcs respectively), a subduction polarity change along the Gander margin of Avalonia led to the formation of the Exploits arc and the opening of the Middle Ordovician Tetagouche/Exploits back- arc basin. British and Irish Ordovician volcano-sedimentary assemblages show similar relationships, although their lateral continuity is disrupted by major sinistral faults. Early Ordovician calc-alkaline volcanic rocks from south Wales are correlated with the Gander arc, while LlanvirnianCaradocian bimodal basalt-rhyolite volcanism of Wales and Leinster equate with the Tetagouche-Exploits back-arc basin. Llandeilian-Caradocian calc-alkaline extrusives from Slieve Aughty, the southwestern Longford-Down inlier and Grangegeeth in Ireland, and the English Lake District are extensions of the Exploits arc, which formed by trenchward migration of the rifted Gander arc during opening of the 
Tetagouche/Exploits back-arc basin. The early Ordovician Notre Dame arc equates with the South Mayo volcanics, Ireland, and the Ballantrae Complex in Scotland. In this reconstruction, Exploits arc equivalent rocks occur north of the so-called
"Iapetus Suture" in Ireland, but south of it in England. Our work suggests that the true suture in the British Isles extends east-west, north of the mid-Ordovician arc volcanics, and is displaced by northeast-trending strike-slip faults. 